Supporting Information

\title{
Luciferin-bioinspired click ligation enables hydrogel platforms with fine-tunable properties for 3D cell culture
} Minye Jin ${ }^{1,2 \pi}$, Gülistan Koçer ${ }^{1}$, and Julieta I. Paez ${ }^{1 \uparrow *}$

1: INM - Leibniz Institute for New Materials, Campus D2-2, 66123, Saarbrücken, Germany.

2: Chemistry Department, Saarland University, 66123 Saarbrücken, Germany.

ๆ: Present address: Developmental BioEngineering Department, TechMed Centre, and Molecules Centre. University of Twente, Drienerlolaan 5, 7522 NB Enschede, The Netherlands.

Corresponding author email: j.i.paez@utwente.nl 


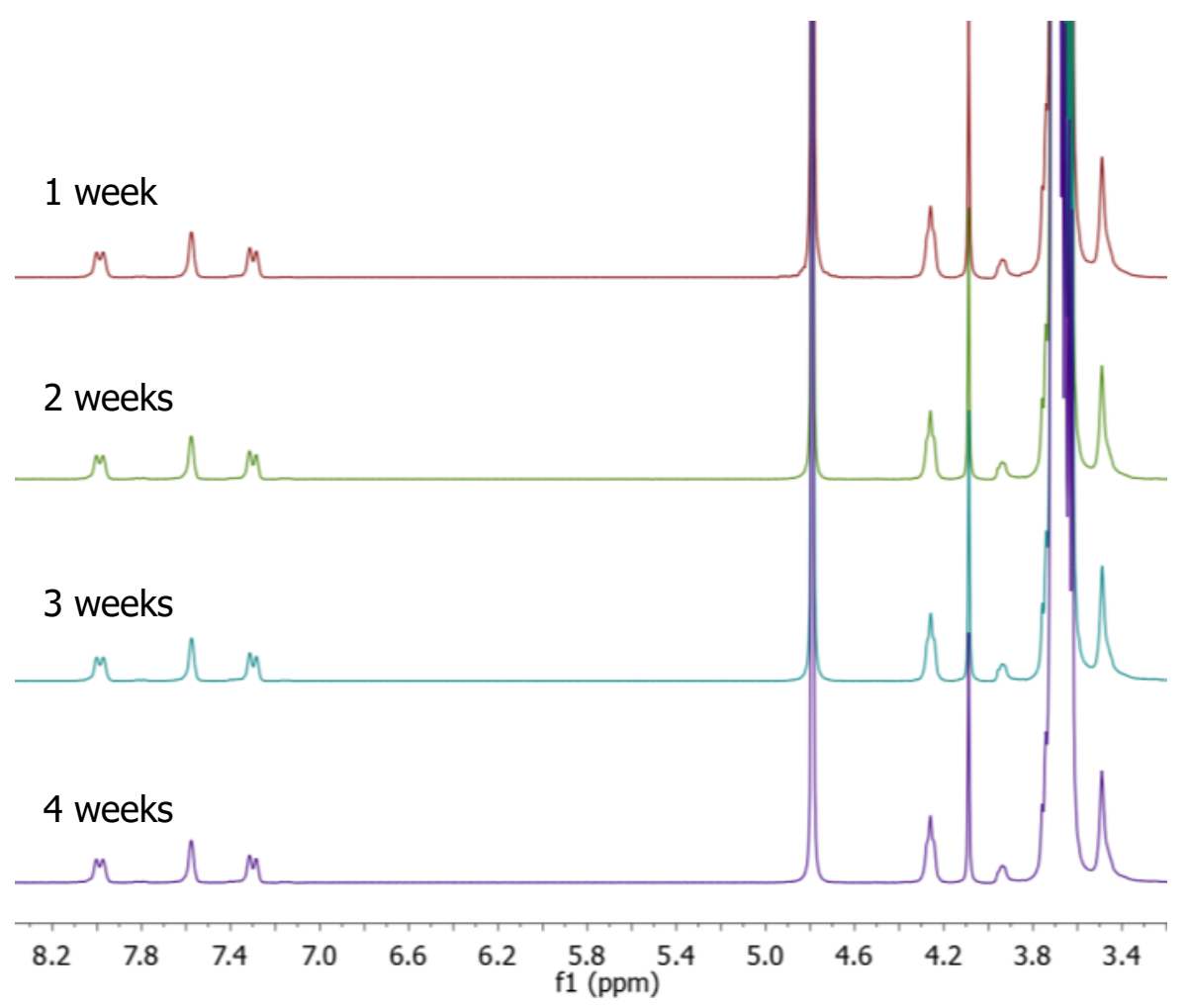

Figure S1. Stability study of an aqueous solution of PEG-CBT macromer over 4 weeks of storage at room temperature, as measured by ${ }^{1} \mathrm{H}$ NMR. Conditions: 4-arm, $5000 \mathrm{~g} \mathrm{~mol}^{-1} \mathrm{PEG}, 6 \mathrm{mM}$ $\left(30 \mathrm{mg} \mathrm{mL}^{-1}\right)$ solution in deuterated PBS buffer (d-PBS) at $25^{\circ} \mathrm{C}$. The PEG-CBT macromer solution was prepared in deuterated PBS buffer and ${ }^{1} \mathrm{H}$ spectra were recored at increasing aging times $\mathrm{t}=1,2,3$, and 4 weeks. During the aging period, samples were stored at room temperature and exposed to normal light conditions in the laboratory. The evolution of the proton signals corresponding to the benzothiazole aromatic ring bound to PEG were monitored. No differences were found in the spectra measured within 4 weeks, indicating high stability of the precursor solution. 
a)

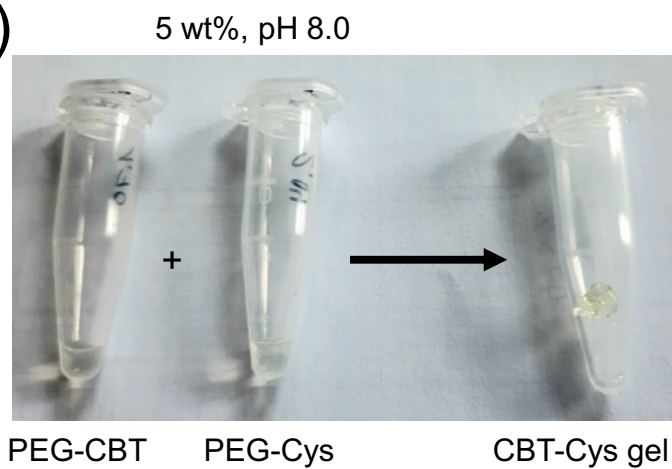

b)

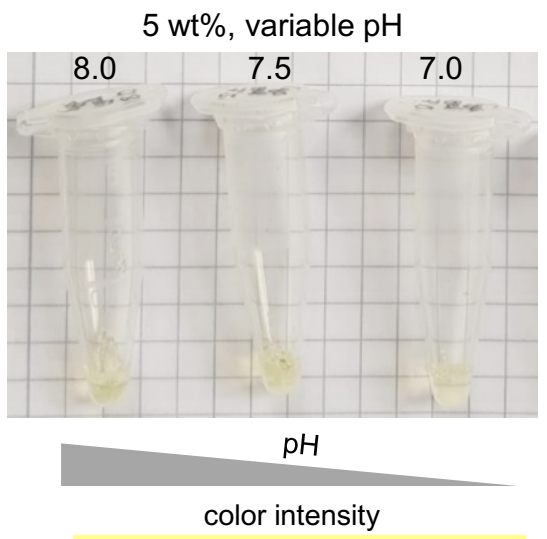

variable polymer content, $\mathrm{pH} 8.0$

c)

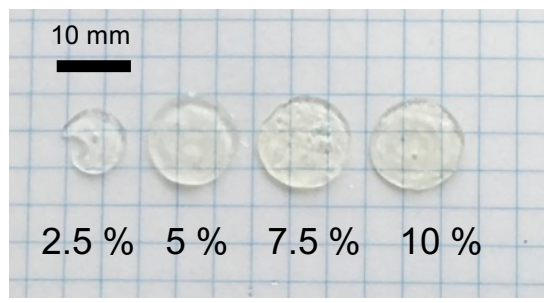

$$
\begin{gathered}
\text { polymer concentration } \\
\text { color intensity }
\end{gathered}
$$

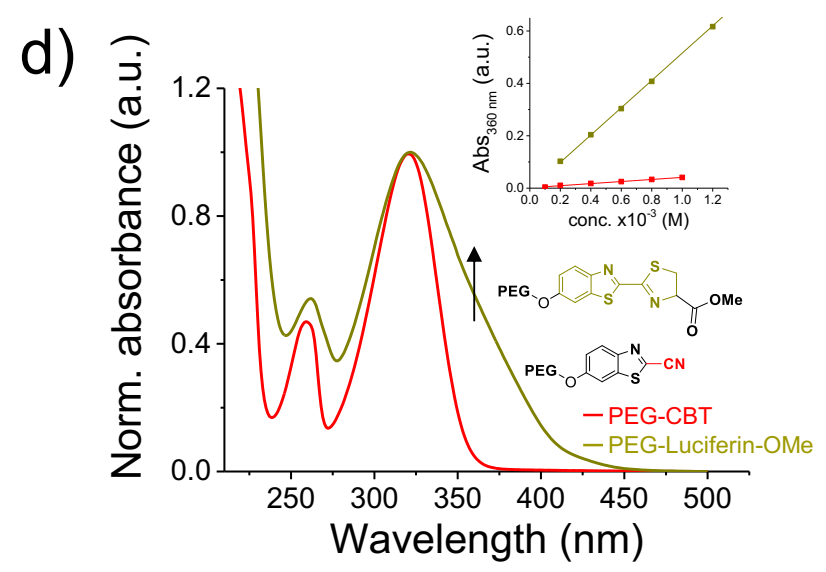

Figure S2. Study of optical properties of CBT-Cys hydrogels (4-arm, $20000 \mathrm{~g} \mathrm{~mol}^{-1}$ ). a) Photograph of precursors and derived CBT-Cys gel, showing the yellow color of the material. b) Photographs of CBT-Cys gels showing no obvious variation in color intensity at variable $\mathrm{pH}$ but c) increased color intensity at increasing polymer content. d) UV/Vis spectra of PEG-CBT vs. PEG-Luciferin-OMe model compound. The arrow indicates the increase of absorbance at $\lambda>340$ $\mathrm{nm}$ in PEG-Luciferin. Insert: determination of molar absorption coefficient $\left(\varepsilon_{360} \mathrm{~nm}\right)$ of the macromers.

PEG-CBT and PEG-Luciferin-OMe macromers were dissolved in 20 mM HEPES buffer ( $\mathrm{pH}$ 8.0) at room temperature to reach functional group concentrations of 0.1 to $1 \mathrm{mM}$ and 0.17 to $1.4 \mathrm{mM}$ respectively. The solutions were loaded into a quartz cuvette (optical path $b=0.1 \mathrm{~cm}$ ) and UV absorption was recorded between 200-500 $\mathrm{nm}$ wavelength range. The absorbance $(A b s)$ at $\lambda=360$ $\mathrm{nm}$ as a function of concentration $(c)$ was plotted and fitted to a linear function according to the Lambert-Beer law: 


$$
A b s=\varepsilon b c
$$

The molar absorption coefficient $(\varepsilon)$ was calculated from the slope of the curve. Values are shown in Table S1.

Table S1. Determination of molar absorption coefficient of PEG-CBT and model PEG-LuciferinOMe macromers at $360 \mathrm{~nm}$.

\begin{tabular}{|l|l|l|l|}
\hline Macromer & slope $360 \mathrm{~nm}=\varepsilon x b\left[\mathrm{M}^{-1}\right]^{\text {a) }}$ & $\varepsilon_{360 \mathrm{~nm}}\left[\mathrm{M}^{-1} \mathrm{~cm}^{-1}{ }^{\text {b) }}\right.$ & rel. value \\
\hline PEG-CBT & 39.64 & 396 & 1.0 \\
\hline PEG-Luciferin-OMe & 521.24 & 5210 & 13.2 \\
\hline
\end{tabular}

a) Determined from the plot of absorbance as a function of concentration, at $\lambda=360 \mathrm{~nm}$, in 20 $\mathrm{mM}$ HEPES buffer $\mathrm{pH} 8,25^{\circ} \mathrm{C} .{ }^{\text {b) }}$ Calculated according to Lambert-Beer law, considering optical path $b=0.1 \mathrm{~cm}$. 


\section{PEG-CBT precursor}

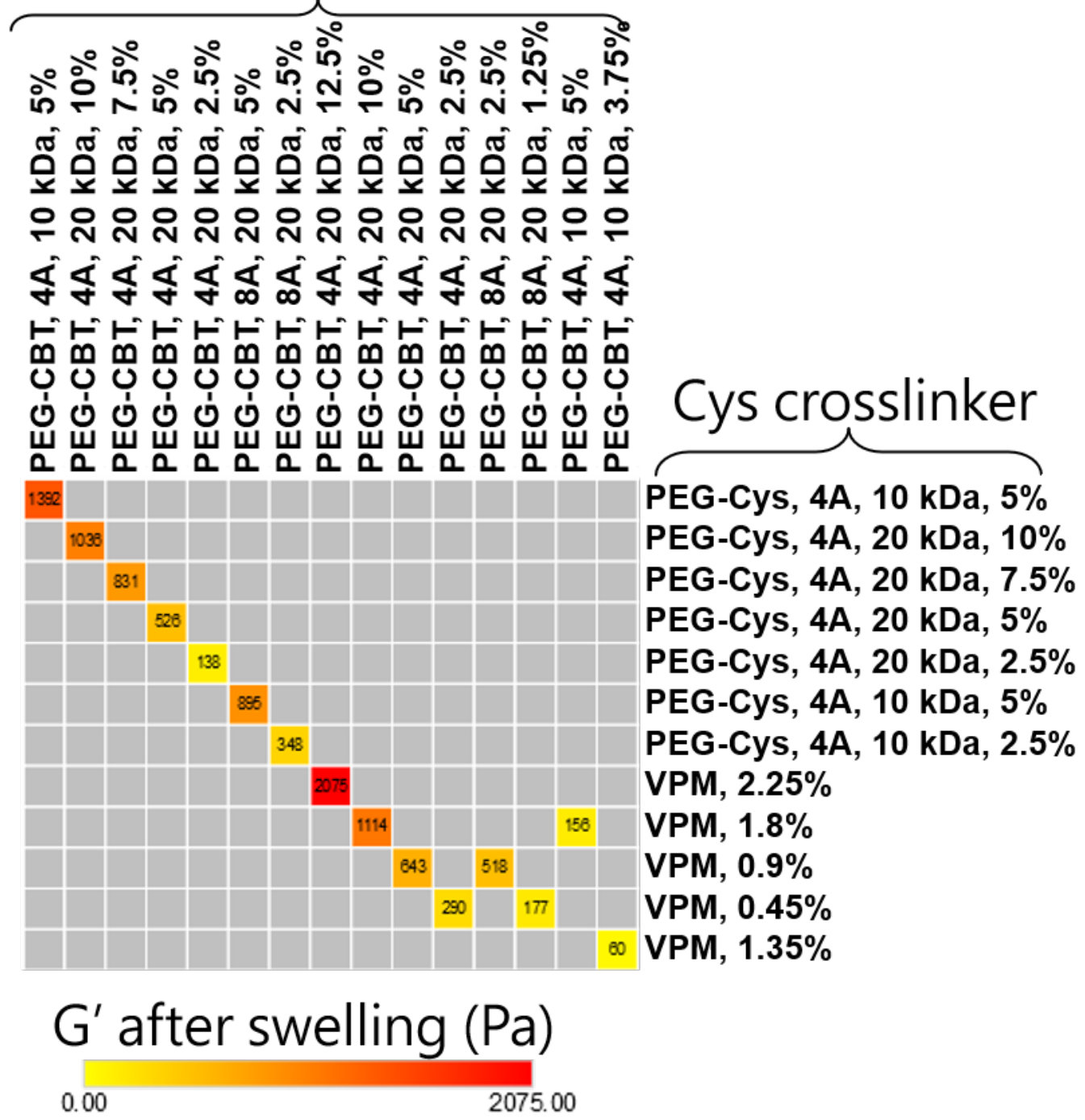

Figure S3. Tunability of mechanical strength of CBT-Cys gels within physiologically relevant values for $3 \mathrm{D}$ cell encapsulation, as a function of the gel composition (final concentration of precursors is shown in each case). Heat map shows G' after swelling for CBT-Cys gels of variable PEG content (1.25 to $12.5 \mathrm{wt} \%$ ), precursor molar mass (10000 vs. $20000 \mathrm{~g} \mathrm{~mol}^{-1}$ ), multivalency (4-arm vs. 8-arm) and topology (4-arm vs. linear Cys crosslinker (VPM) of $1800 \mathrm{~g} \mathrm{~mol}^{-1}$ ). Conditions: gels were prepared at constant CBT:Cys molar ratio (1:1) in 20 mM HEPES buffer $\mathrm{pH} 8.0$, cured for $2 \mathrm{~h}$ at $25^{\circ} \mathrm{C}$ and swelled until equilibrium ( $\left.24 \mathrm{~h}\right)$ in same buffer. G' after swelling was measured by rheology following the protocol specified in the main text. 
a)

\section{PEG-CBT precursor}

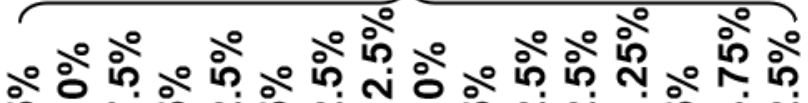

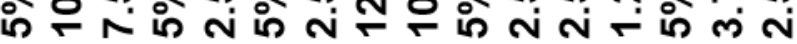

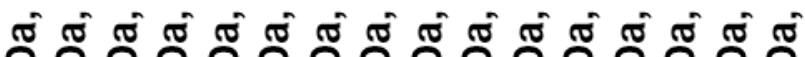

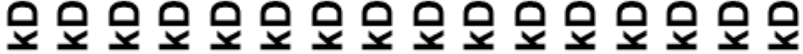

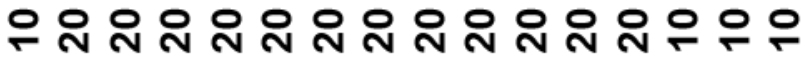

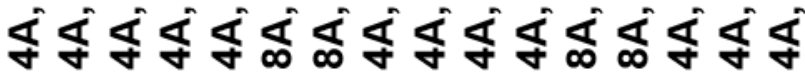
ドドドドドドドドドドドドドドドド $\boldsymbol{m} \boldsymbol{m} \boldsymbol{m} \boldsymbol{m} \boldsymbol{m} \boldsymbol{m} \boldsymbol{m} \boldsymbol{m} \boldsymbol{m} \boldsymbol{m} \boldsymbol{m} \boldsymbol{m} \boldsymbol{m}$ U

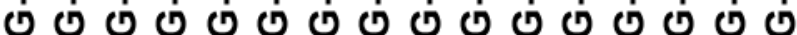

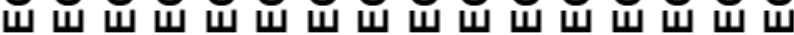

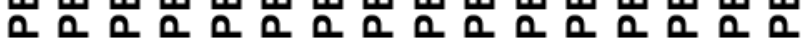

\section{Cys crosslinker} 10

PEG-Cys, 4A, $10 \mathrm{kDa}, 5 \%$

8 PEG-Cys, 4A, $20 \mathrm{kDa}, 10 \%$ PEG-Cys, 4A, $20 \mathrm{kDa}, 7.5 \%$ PEG-Cys, 4A, $20 \mathrm{kDa}, 5 \%$ PEG-Cys, 4A, $20 \mathrm{kDa}, 2.5 \%$ 9 PEG-Cys, 4A, $10 \mathrm{kDa}, 5 \%$ PEG-Cys, 4A, $10 \mathrm{kDa}, 2.5 \%$

10 VPM, $2.25 \%$

VPM, $1.8 \%$

VPM, $0.9 \%$

VPM, $0.45 \%$

VPM, $1.35 \%$

Gelation time (s) 
b)

Effect of polymer content

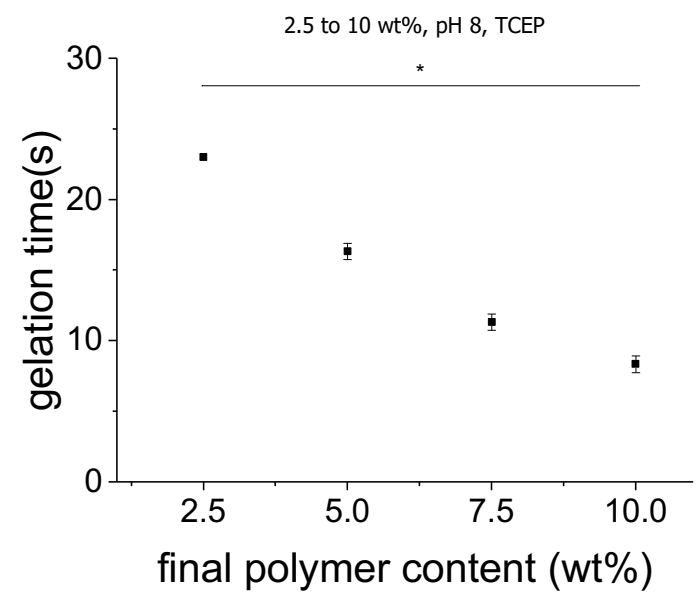

\section{Effect of $\mathrm{pH}$ and reductant}

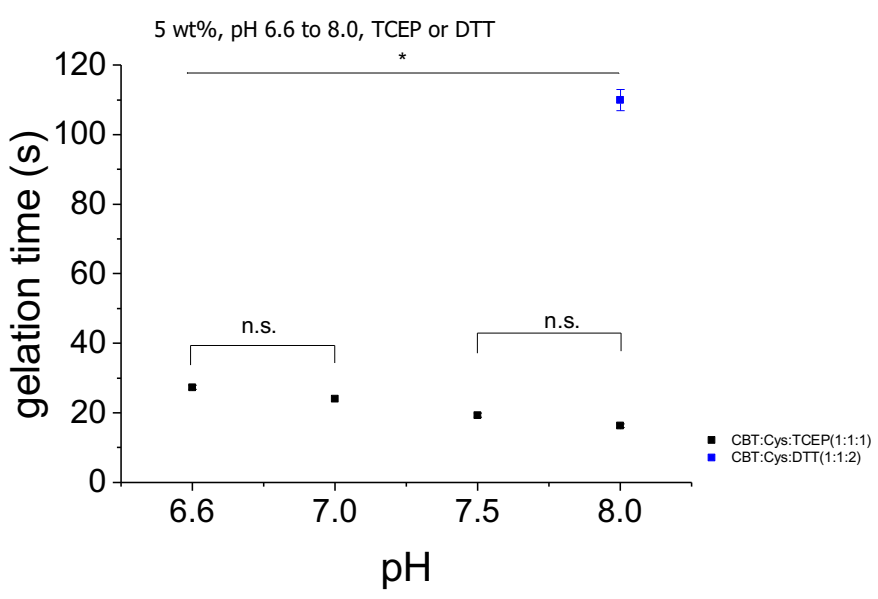

Figure S4. Tunability of gelation time of CBT-Cys gels, as a function of the gel composition (final concentration of precursors is shown in each case). a) Heat map at $\mathrm{pH} 8.0$ shows gelation time as a function of variable polymer content ( 1.25 to $12.5 \mathrm{wt} \%$ ), precursor molar mass (10000 vs. 20000 $\mathrm{g} \mathrm{mol}^{-1}$ ), multivalency (4-arm vs. 8-arm), and network topology (4-arm vs. linear Cys crosslinker (VPM) of $1800 \mathrm{~g} \mathrm{~mol}^{-1}$ ). b) Gelation time as a function of polymer content (left) and $\mathrm{pH}$ and reductant (right). Mean \pm SD shown $(n=3)$. Conditions: gels were prepared at constant CBT:Cys molar ratio (1:1) in $20 \mathrm{mM}$ HEPES buffer, at $25^{\circ} \mathrm{C}$. Gelation time was estimated by the "pipetting" macroscopic test, following the protocol specified in the main text. Statistical significance analysis was performed by ANOVA followed by post-hoc Tukey test $\left({ }^{*} \mathrm{p}<0.05\right.$ used for statistical significance; n.s. $=$ not significant). 
a) $5 \mathrm{wt} \%$ gels, cured for $1.5 \mathrm{~h}$

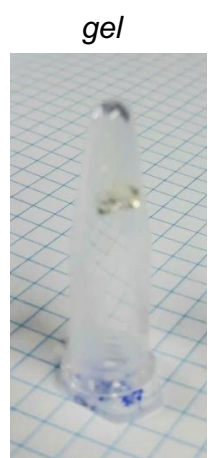

CBT-Cys

(TCEP)

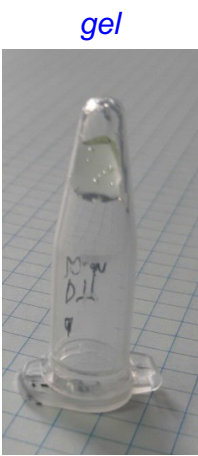

CBT-Cys

(DTT)

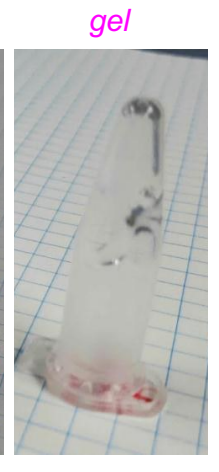

CBT

(no Cys, in DTT) after incubation in HEPES

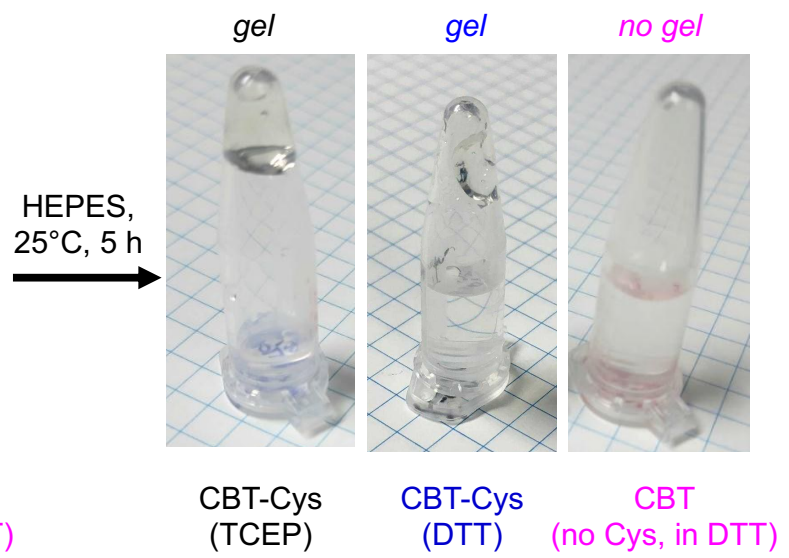

b) pre-curing incubation in HEPES buffer
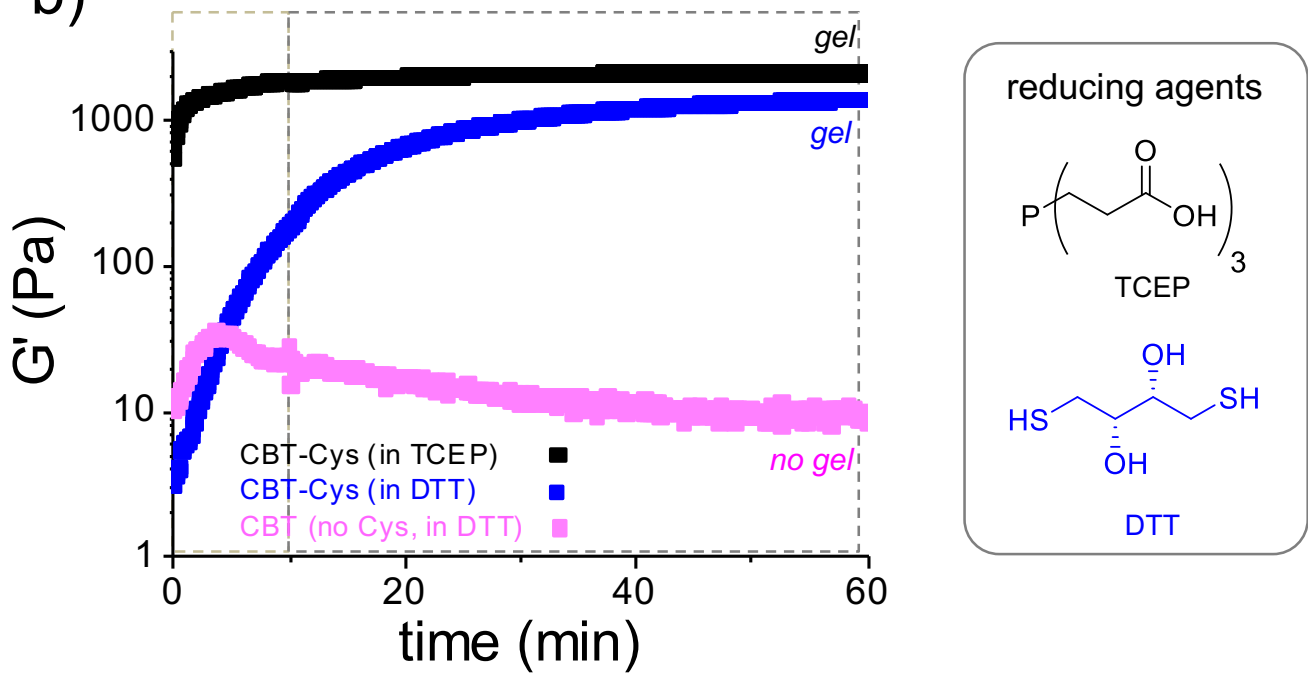

C)
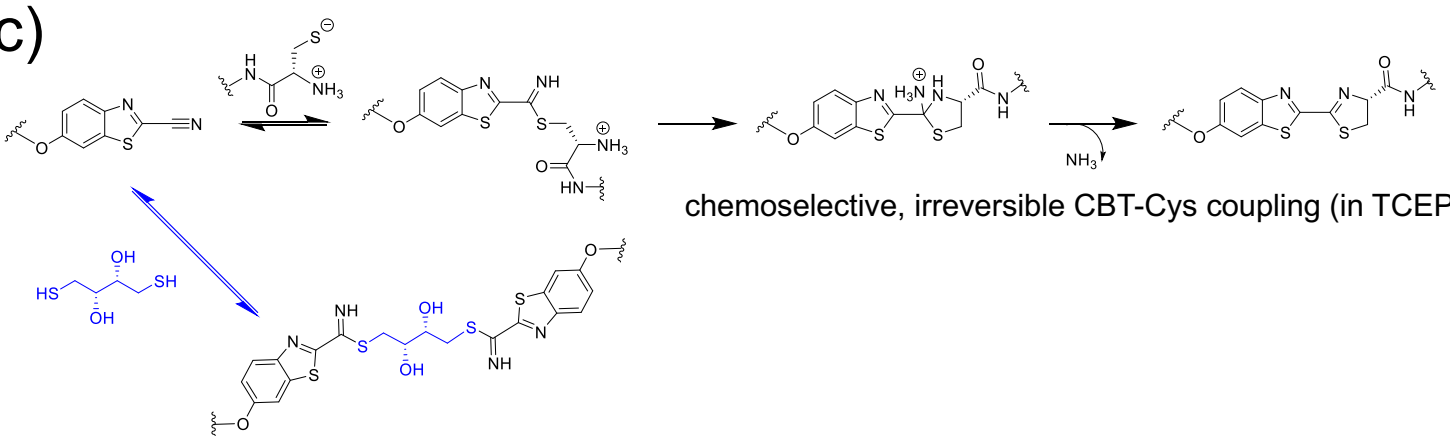

chemoselective, irreversible CBT-Cys coupling (in TCEP)

additional reversible CBT-thiol coupling (in DTT)

Figure S5. Differences between CBT-Cys gels prepared in presence of different reducing agents, TCEP vs. DTT. a) Macroscopic CBT-Cys gels were prepared by mixing CBT and Cys precursors in the presence of $20 \mathrm{mM}$ TCEP (black) or DTT (blue), cured for $1.5 \mathrm{~h}$ and then incubated in 
HEPES buffer for $5 \mathrm{~h}$ at $25^{\circ} \mathrm{C}$. Both gels remained stable. As control sample, CBT precursor was mixed with $5 \mathrm{mM}$ DTT in the absence of Cys precursor (pink). A soft gel was obtained in around $1 \mathrm{~min}$, which dissolved completely in $<3$ min upon incubation in buffer. An equivalent experiment was conducted on the rheometer, as shown in b). Gels of same composition were prepared in situ, pre-cured in air for $10 \mathrm{~min}$ and then immersed in HEPES buffer for the rest of the time sweep experiment. DTT-containing CBT-Cys gels show slower gelation kinetics (blue curve) than TCEPcontaining analogue materials (black curve), however both remain stable at the end of the experiment (final $\mathrm{G}^{\prime} \sim 1000 \mathrm{~Pa}$ ). In a control experiment, in absence of Cys precursor, CBT precursor mixed with $5 \mathrm{mM}$ DTT forms a very soft gel $\left(\mathrm{G}^{\prime} \sim 30 \mathrm{~Pa}\right)$ that degrades completely upon swelling (pink curve). c) Chemical mechanisms of CBT-Cys coupling ${ }^{1}$ expected in presence of TCEP and the additional CBT-thiol coupling that takes play in DTT. 
a)

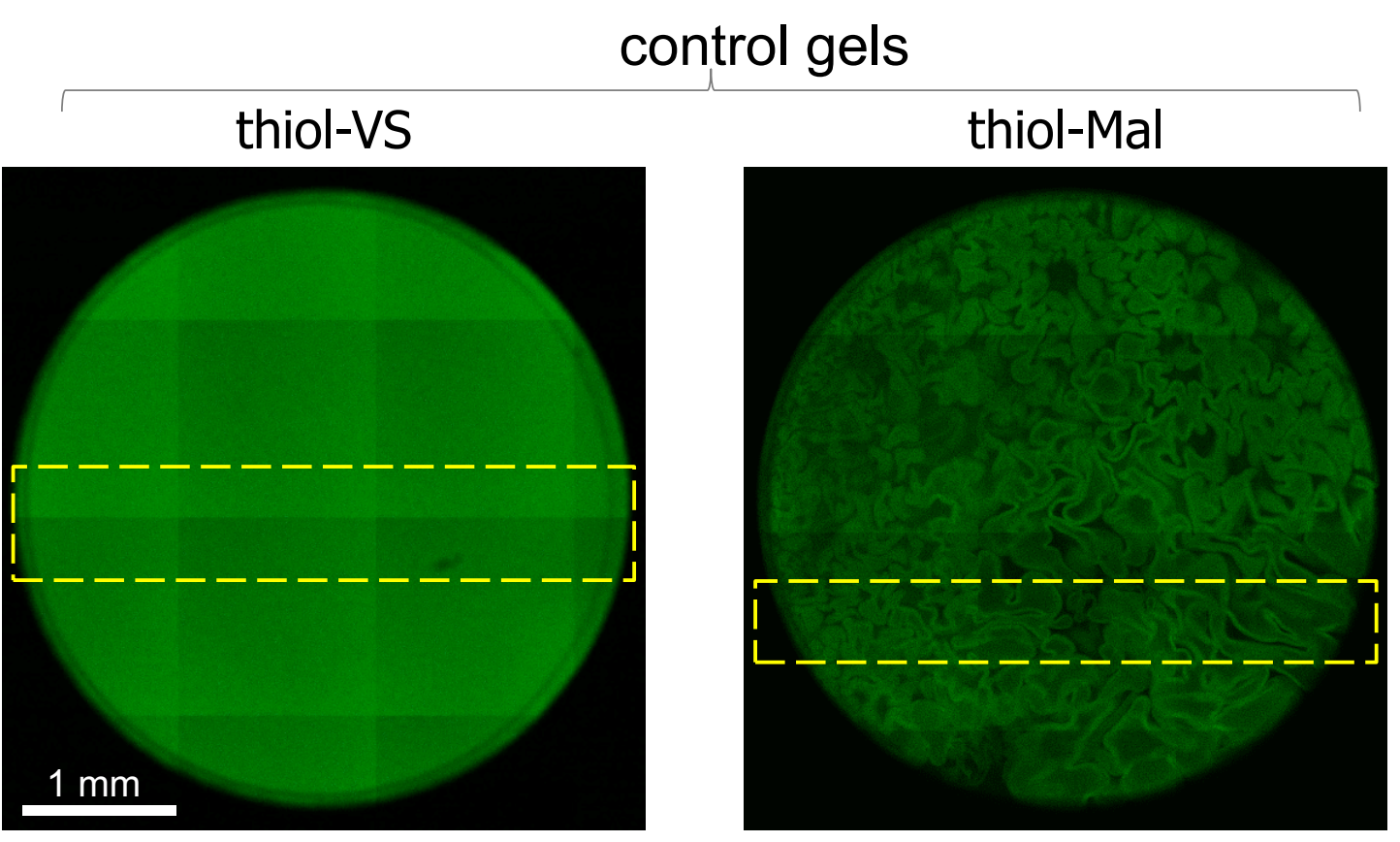

b)
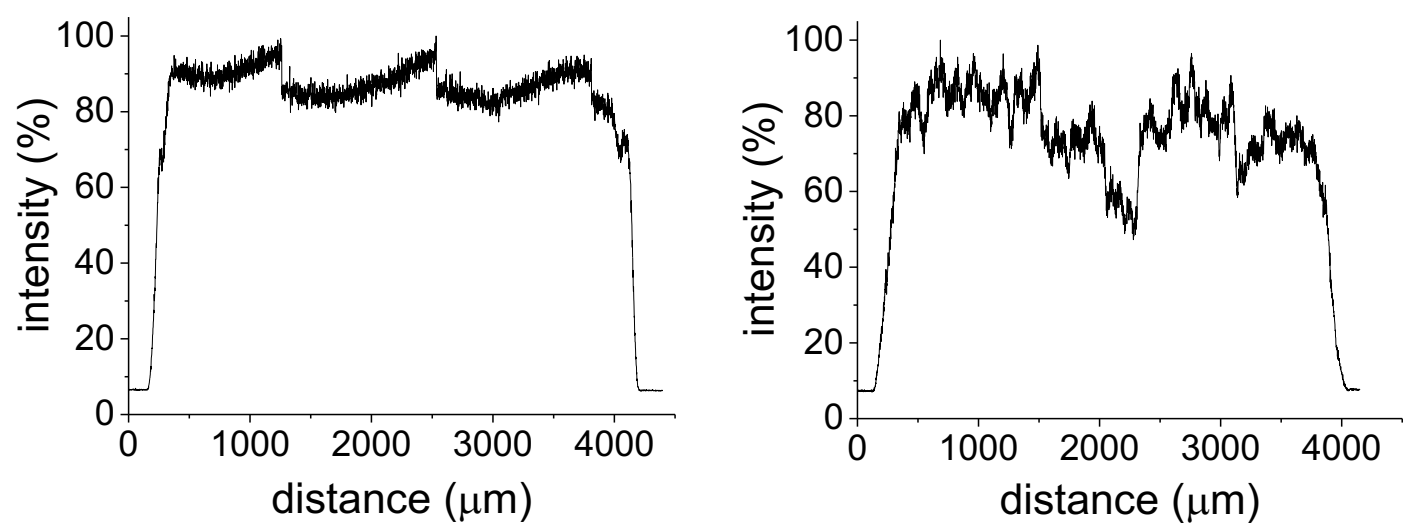

Figure S6. Microscale homogeneity of thiol-VS and thiol-Mal control gels. a) Fluorescence confocal microscopy image of fluorescently labeled gels, scale bar $=1 \mathrm{~mm}$. b) Normalized intensity distribution of the gels as a function of distance, following the region of interest (indicated by the yellow rectangles). Conditions: 4-arm, $20000 \mathrm{~g} \mathrm{~mol}^{-1}, 5 \mathrm{wt} \%$ gel, labelled with $0.01 \mathrm{mM}$ AlexaFluor 555. 
a)
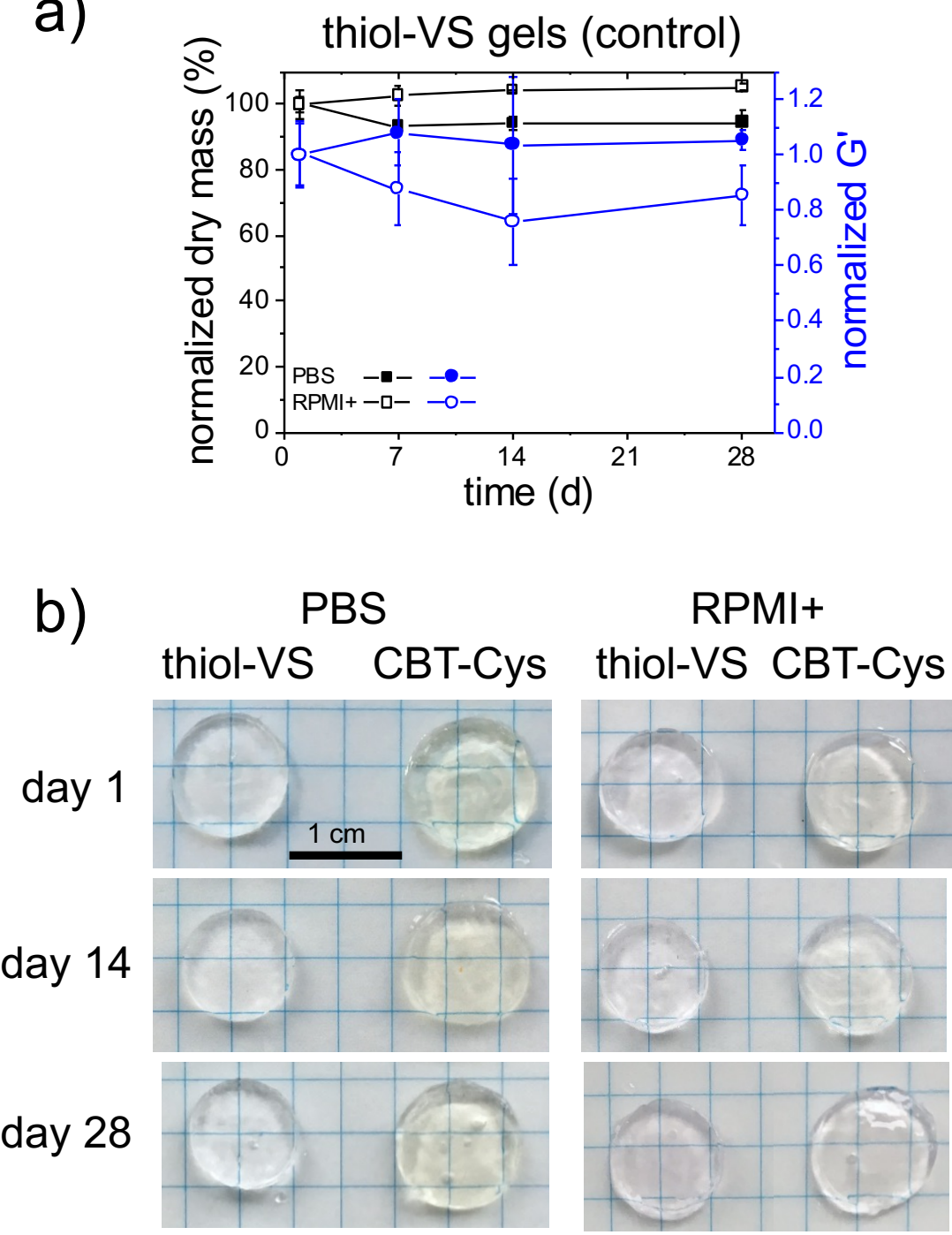

Figure S7. a) Stability study of thiol-VS control gels by following the evolution of mass and G' as a function of incubation time (mean \pm SD shown, $n=3$ ). Thiol-VS gels showed a high mass retention both in PBS (94 $\pm 4 \%$ at day 28$)$ and in RPMI+ (105 $\pm 1 \%$ at day 28$)$. In the latter, the slight mass gain observed is presumably due to non-specific absorption of serum proteins on the gel. Additionally, G' remained unaltered in PBS by day 28 , while it decreased to $85 \%$ of the initial value upon incubation in RPMI+. b) Pictures showing CBT-Cys gels vs. thiol-VS gels upon incubation at days 1, 14 and 28. CBT-Cys gels showed gradual discoloration in RPMI+. Conditions: 4-arm, $20000 \mathrm{~g} \mathrm{~mol}^{-1}, 5 \mathrm{wt} \%$ gels, incubated in PBS or RPMI+ (pH 7.4) at $37{ }^{\circ} \mathrm{C}$ for 4 weeks. 


\section{encapsulation of L929 fibroblasts in CBT-Cys gels}
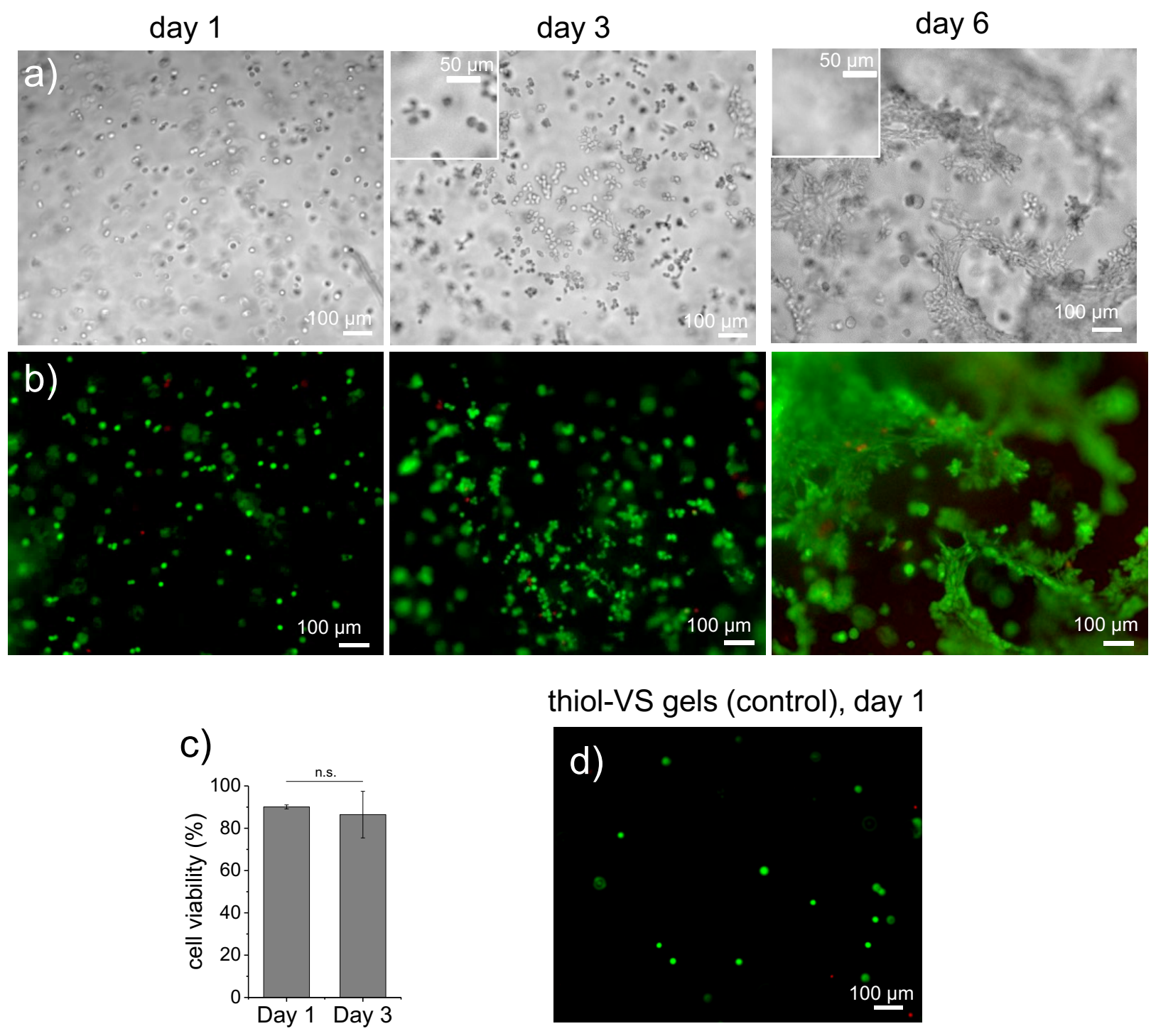

thiol-VS gels (control), day 1

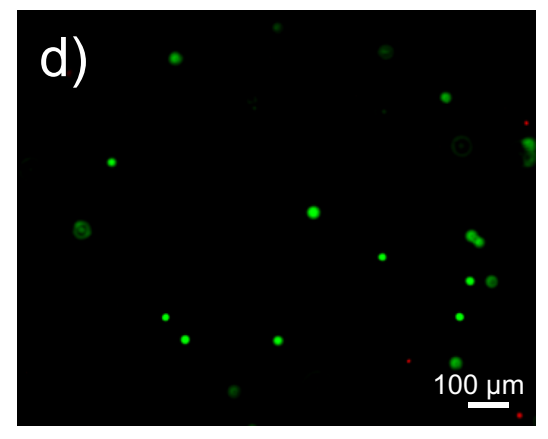

Figure S8. Encapsulation of L929 fibroblasts in CBT-Cys hydrogels for 1, 3, and 6 days. a) representative brightfield images, b) live (green)/ dead (red) staining for these cells, and c) cell viability quantification. CBT-Cys gel composition: 4-arm, $20000 \mathrm{~g} \mathrm{~mol}^{-1}$, 4 wt\% PEG-CBT, 0.07 wt\% (1 mM) cyclo(RGDfK(C)), 0.64 wt\% (3.5 mM) VPM peptide, starting cell density per gel was 20000 cells. Cells were cultured in complete culture medium. d) Thiol-VS gels at similar composition was included as control, cultured for 1 day, live/dead staining was performed, and cell viability was calculated as $79 \pm 12 \%(\mathrm{n}>600)$. Thiol-VS gel composition: 4-arm, $20000 \mathrm{~g}$ $\mathrm{mol}^{-1}, 4 \mathrm{wt} \%$ PEG-VS, $0.06 \mathrm{wt} \%$ (1 mM) cyclo(RGDfC), $0.64 \mathrm{wt} \%$ (3.5 mM) VPM peptide, cell 
density was 2500 cells per gel. Curing was carried out for $45 \mathrm{~min}$ at room temperature. Scale bars: $100 \mu \mathrm{m}$ (insert: $50 \mu \mathrm{m}$ ). After 3 days of culture, cells recognized the cell-adhesive peptide, as evidenced by formed cell protrusions (Figure S8a, insets). At day 6, cells qualitatively highly populated the gel (Figure S8b) and formed extensive cell-cell contacts again with protruding cells. Since at day 6 highly populating live L929 fibroblast cells (with a starting cell density of 20000 cells per gel) were associated with interior areas of growing cell clusters, a separate experiment of encapsulation was performed at lower cell density (2500 cells per gel), to effectively analyze cell viability. A high cell viability $(90 \pm 1 \%)$ at day 6 post-encapsulation was observed accordingly. Besides, even though we did not quantify the extent of cell elongation and spreading here; fibroblast cell growth, protrusion formation and spreading at days 3 and 6 can be attributed to celladhesive peptide recognition and cell-mediated remodeling in these gels. In addition, when inspected by eye, at day 6 some gel degradation was observed even though was not yet complete and an intact gel piece was still visible. 
encapsulation of hMSCs in CBT-Cys gels, $1 \mathrm{~h}$
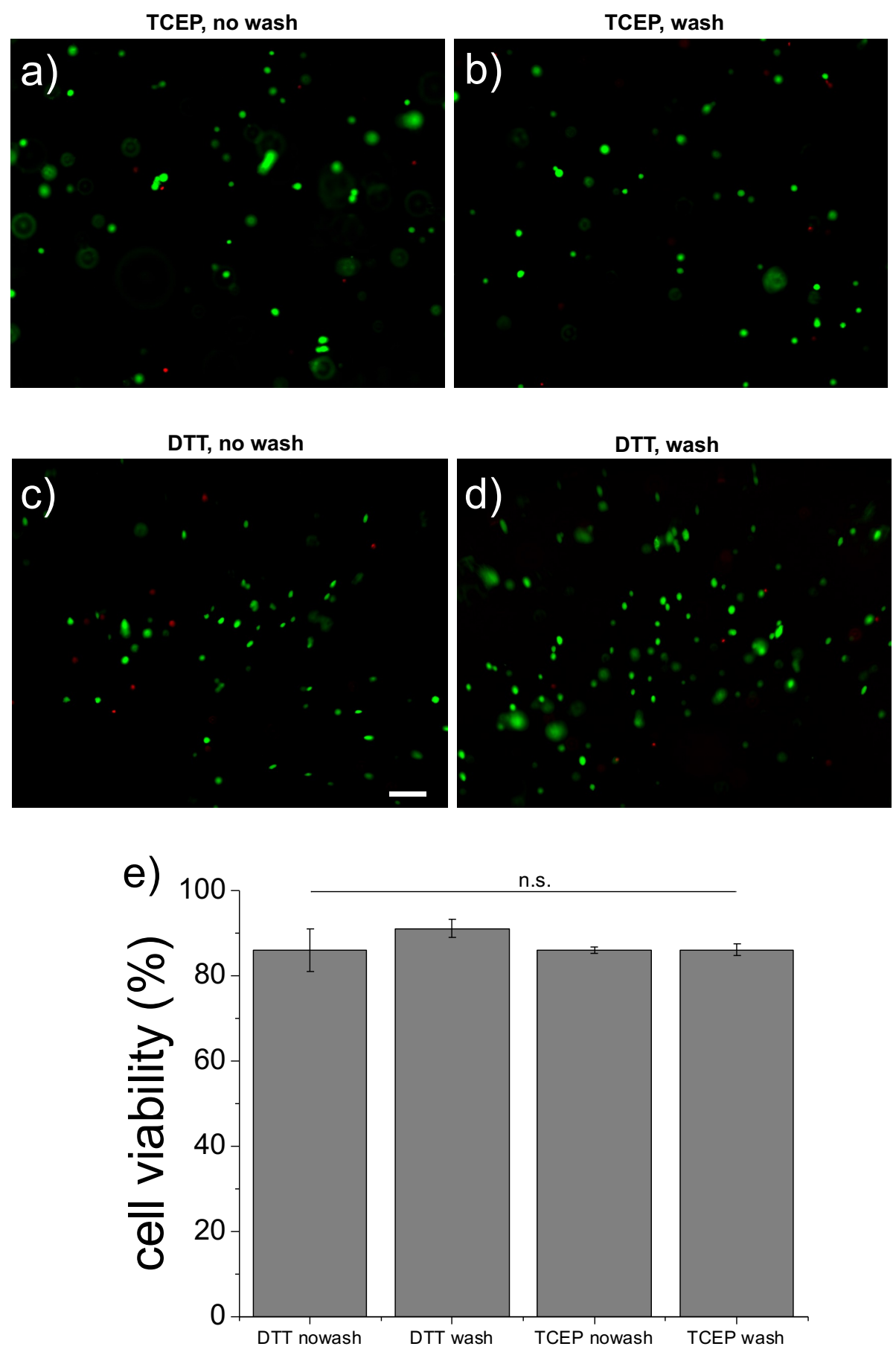

Figure S9. Analysis of the acute toxicity of CBT-Cys hydrogels on embedded hMSCs, at $1 \mathrm{~h}$ postencapsulation, as a function of washing steps after curing and reductant choice. Cell encapsulation was performed in the presence of either TCEP (a-b) or DTT (c-d) as reductant present in the PEGCys precursor solution. Gels were cured for $15 \mathrm{~min}$, and the effect of including a washing step (b, 
d) or not (a, c), prior to adding cell culture medium, was analyzed via live/dead assay, after $1 \mathrm{~h}$ of culture. Scale bar: $100 \mu \mathrm{m}$. e) Quantification of cell viability on gel samples that were prepared under different conditions. In all cases, calculated cell viability was $>86 \%$ and no significant differences were observed among the different groups, either across reductants or washing protocols. CBT-Cys gel composition (+VPM/+RGD): 4-arm, $20000 \mathrm{~g} \mathrm{~mol}^{-1}$, 4 wt\% PEG-CBT, $0.07 \mathrm{wt} \%(1 \mathrm{mM})$ cyclo(RGDfK(C)), $0.64 \mathrm{wt} \%$ (3.5 mM) VPM peptide, starting cell density per gel was 5000 cells. Statistical significance analysis was performed by ANOVA followed by posthoc Tukey test $(* \mathrm{p}<0.05$ used for statistical significance; n.s. $=$ not significant $)$. 


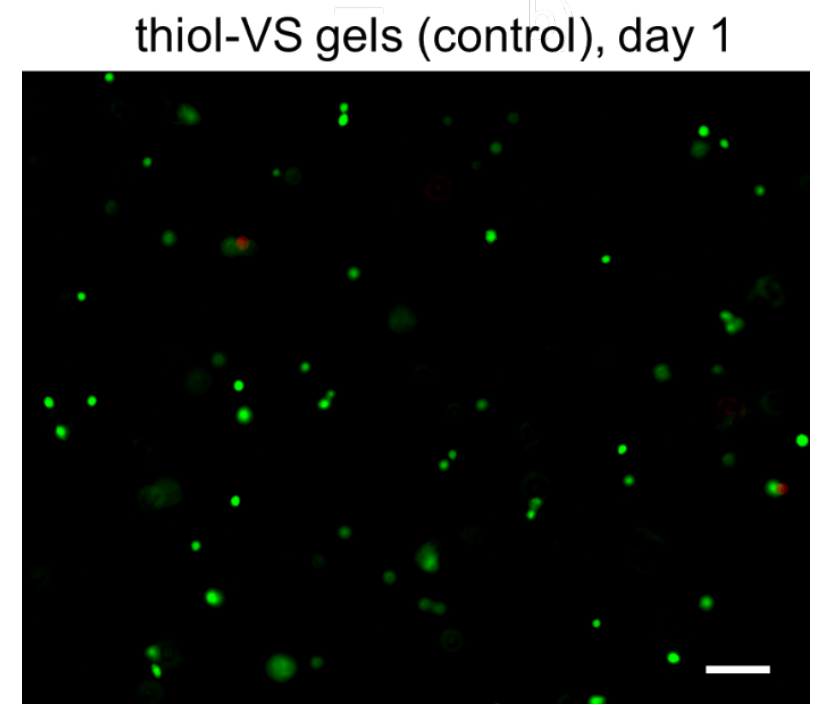

Figure S10. A representative image for hMSC viability analysis in thiol-VS control gels at day 1 post-encapsulation (scale bar: $100 \mu \mathrm{m}$, red: dead and green: live cells). In this case, calculated cell viability was $89 \pm 1 \%(n>600)$. 
a)

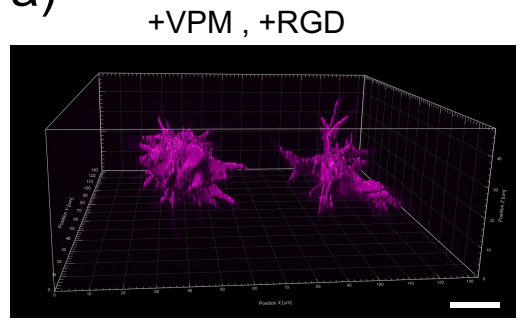

b)

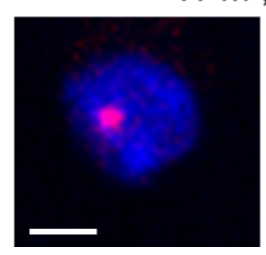

encapsulation of hMSCs in CBT-Cys gels, day 2

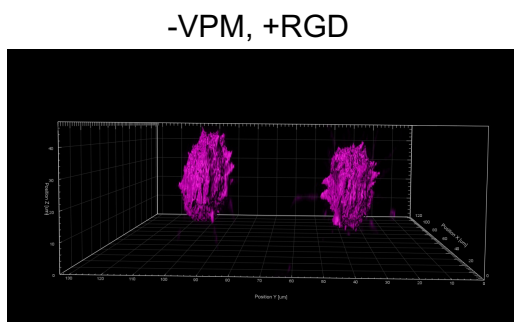

-VPM, +RGD

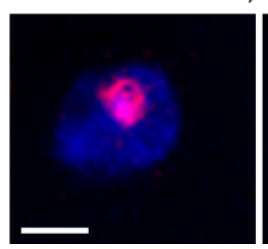

+VPM, -RGD

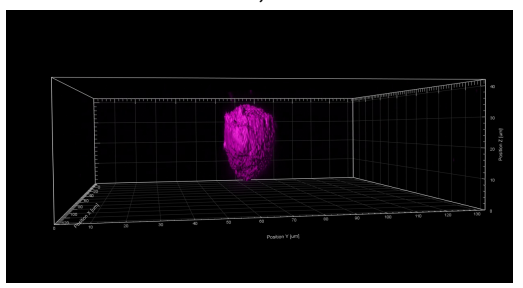

+VPM, -RGD
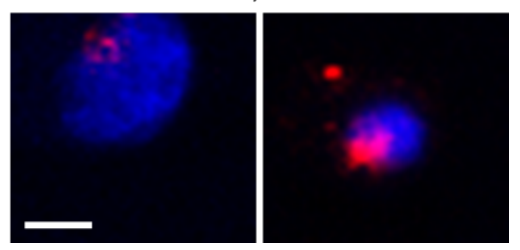

Figure S11. Analysis of hMSCs morphology (a) and proliferation ability (b) in CBT-Cys gels of variable degradability and cell-adhesiveness (+/-VPM and +/-RGD), at 2 days post-encapsulation. a) Representative $3 \mathrm{D}$ rendered images using $\mathrm{F}$-actin intensities for volume and sphericity analysis with Imaris software (using surfaces function). Volume calculation was based on number of voxels, and both parameters were automatically calculated by using Imaris software. Scale bar $=$ $20 \mu \mathrm{m}$. b) Representative images of Ki67 protein colocalization in cell nucleus (Red: Ki67, blue: nucleus, scale bar $=5 \mu \mathrm{m}$ ). In order to calculate the percentage of Ki67 $7^{+}$nuclei, 20X (air objective) images were used for counting cells (number of cells that were used in analysis was 22, 40 and 27 for +VPM/+RGD, -VPM/+RGD and +VPM/-RGD gels, respectively). Percentages of Ki67 nuclei were: $23 \pm 1 \%, 32 \pm 12 \%$ and $26 \pm 9 \%$ for +VPM/+RGD, -VPM/+RGD and +VPM/RGD conditions, respectively; derived by averaging the percentages of Ki67+ nuclei in gel replicates with the reported number of total cells (mean $\pm \mathrm{SD}$ ). Analysis was performed using Kruskal-Wallis one way-ANOVA for statistical significance. Multiple comparison tests were performed with Mann-Whitney U test by adjusting $\alpha$ level downward according to Bonferroni correction by comparing all groups of interest (OriginPro v.9, OriginLab). No significant difference between different conditions was detected. Gels composition: in +VPM/+RGD condition: $4 \mathrm{wt} \%$ PEG, $0.07 \mathrm{wt} \%$ RGD, $0.64 \mathrm{wt} \% \mathrm{VPM}$; in -VPM/+RGD condition: $1.5 \mathrm{wt} \%$ PEG-CBT, $1.3 \mathrm{wt} \%$ PEG-Cys, $0.03 \mathrm{wt} \%$ RGD, in +VPM/-RGD condition: $4 \mathrm{wt} \%$ PEG, $0.64 \mathrm{wt} \%$ VPM; starting cell density per gel was 5000 cells. 


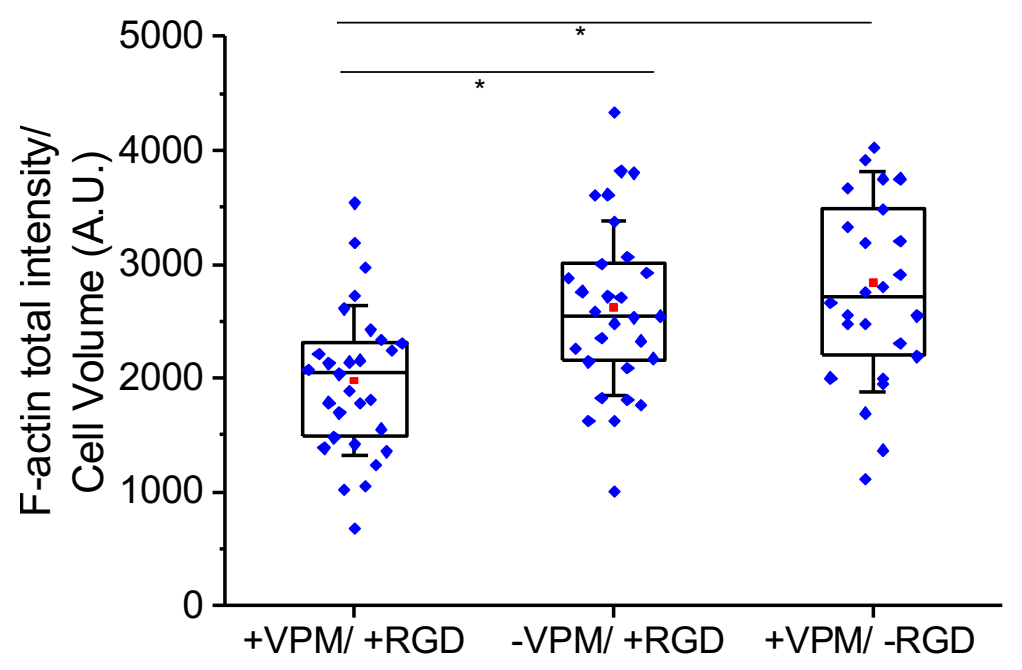

Figure S12. Quantification of F-actin intensity per cell volume for hMSCs cultured in CBT-Cys gels of variable degradability and cell-adhesiveness (+/-VPM and +/-RGD), at 2 days postencapsulation. Gels composition: in +VPM/+RGD condition: $4 \mathrm{wt} \%$ PEG, $0.07 \mathrm{wt} \%$ RGD, $0.64 \mathrm{wt} \%$ VPM; in -VPM/+RGD condition: $1.5 \mathrm{wt} \%$ PEG-CBT, $1.3 \mathrm{wt} \%$ PEG-Cys, $0.03 \mathrm{wt} \%$ RGD; and in +VPM/-RGD condition: $4 \mathrm{wt} \%$ PEG, $0.64 \mathrm{wt} \%$ VPM.

Table S2. Quantification of F-actin intensities in cells in different CBT-Cys gels. $t=2$ days ( $\mathrm{n}=26-$ 29 cells, data are mean $\pm \mathrm{SD}$ ).

\begin{tabular}{|l|l|l|l|}
\hline Condition & $+\mathrm{VPM} /+\mathrm{RGD}$ & -VPM/+RGD & $+\mathrm{VPM} /$-RGD \\
\hline $\begin{array}{l}\text { F-Actin intensity per cell } \\
\left.\text { volume [A.U. } / \mu \mathrm{m}^{3}\right]\end{array}$ & $1978 \pm 659$ & $2617 \pm 768$ & $2841 \pm 969$ \\
\hline $\begin{array}{l}\text { Total F-actin intensity in } \\
\left.\text { cells [A.U./ }\left(10^{6}\right)\right]\end{array}$ & $14.4 \pm 6.9$ & $13.0 \pm 5.6$ & $14.0 \pm 8.5$ \\
\hline Cell volume $\left[\mu \mathrm{m}^{3}\right]$ & $7334 \pm 2679$ & $5035 \pm 1567$ & $5285 \pm 2858$ \\
\hline
\end{tabular}




\section{Supplementary Experimental Section}

\section{General materials and methods}

Reagents were purchased from Fluorochem (Derbyshire, UK), Fluka (Taufkirchen, DE), Merck (Darmstadt, DE), ABCR (Karlsruhe, DE), AcrosOrganics (Geel, BE), Sigma-Aldrich (Steinheim, DE) and Carbolution (St. Ingbert, DE). Solvents had p.a. purity and were used as purchased unless specified. 4-arm (4A) and 8-arm (8A) polyethylene glycol (PEG) polymers, molar mass= 5000, 10000 , and $20000 \mathrm{~g} \mathrm{~mol}^{-1}$; functionalized with amine (PEG-amine) or succinimidyl carboxymethyl ester (PEG-NHS) were purchased from Jenkem (USA). 4A, $20000 \mathrm{~g} \mathrm{~mol}^{-1}$ PEG-thiol, PEG-Mal and PEG-VS macromers used for preparation of control gels were purchased from Jenkem.

Buffer solutions were freshly prepared. 20 mM HEPES buffers (pH 8.0; 7.5, 7.0 and 6.6), with and without TCEP were used. Deuterated solvents were obtained from Deutero GmbH (Kastellaun, DE). Deuterated phosphate-buffer saline (d-PBS) at $\mathrm{pD}=7.6(\mathrm{pH}=8.0)$ was prepared by dissolving the proper amount of disodium phosphate, monosodium phosphate, sodium chloride and potassium chloride in $\mathrm{D}_{2} \mathrm{O}$; followed by pD adjustment using $40 \% \mathrm{DCl}$ solution (Merck) or $40 \% \mathrm{NaOD}$ solution until reaching desired $\mathrm{pD}$ value. $\mathrm{pH}$ value was monitored by $\mathrm{pH}$-meter and the following correction factor was applied: $\mathrm{pD}=\mathrm{pH}$ obs +0.4 .

Thin layer chromatography (TLC) plates (ALUGRAM® SIL G/UV254) and silica gel for column chromatography (60 ̊̊ pore size, 63-200 $\mu \mathrm{m}$ particle size) were obtained from MachereyNagel (Düren, DE). TLC plates were observed under 254 or $365 \mathrm{~nm}$ light. Silica gel flash column chromatography purification of the compounds was performed with a high-performance Biotage ${ }^{\circledR}$ Selekt System (Uppsala, SE), equipped with a UV/Vis detector and fraction collector. Biotage ${ }^{\circledR}$ Sfär Bio C18 D columns (300 Å pore size, $20 \mu \mathrm{m}$ particle size, $50 \mathrm{~g}$ filling) were used as stationary phase. Solvent gradients using a combination of the following eluents were used: solvent A (MilliQ 
water) and solvent B (acetonitrile, ACN), typically over 30 min duration. HPLC analysis and purification of the compounds were performed with a HPLC JASCO 4000 (JP) equipped with a diode array, UV/Vis detector and fraction collector. Reprosil C18 columns were used for semipreparative $(250 \times 25 \mathrm{~mm})$ and analytical $(250 \times 5 \mathrm{~mm})$ runs. Solvent gradients using a combination of the following eluents were used: solvent A (MilliQ water $+0.1 \%$ TFA) and solvent B (95\% ACN $/ 5 \%$ MilliQ water $+0.1 \%$ TFA), typically over 40 min duration. Purification of modified polymers was typically performed by dialysis against acetone and water. Spectra/Por 3 dialysis tubing (molecular weight cut-off $\mathrm{MWCO}=3.5 \mathrm{kDa}$ ) from Spectrum Chemical (USA) was used.

Solution ${ }^{1} \mathrm{H}-\mathrm{NMR}$ and ${ }^{13} \mathrm{C}$-NMR spectra were recorded at $25{ }^{\circ} \mathrm{C}$ on a Bruker Avance $300 \mathrm{MHz}$ or on a Bruker Avance III UltraShield $500 \mathrm{MHz}$. The latter was equipped with a He-cooled $5 \mathrm{~mm}$ TCI-CryoProbe, a proton-optimized triple resonance NMR 'inverse' probe with external water cooling unit (CP TCI 500S2, H-C/N-D-05 Z). Unless otherwise stated, all measurements were taken at $298 \mathrm{~K}$ and the solvent residual peak ( $7.25 \mathrm{ppm}$ for $\mathrm{CDCl}_{3}, 2.05 \mathrm{ppm}$ for acetone- $\mathrm{d}_{6}, 2.50$ ppm for DMSO- $\mathrm{d}_{6}$ and 4.79 ppm for $\mathrm{D}_{2} \mathrm{O}$ ) was employed as internal reference. Chemical shifts ( $\delta)$ are given in parts per million. The following abbreviations are used: s-singlet, d-doublet, ttriplet, q-quartet, m-multiplet, dd-double doublet. The degree of substitution of PEG polymer was calculated by end-group determination. The integral of the signal corresponding to the PEG backbone (3.70-3.40 ppm) was set to $110 \mathrm{H}, 220 \mathrm{H}$ or $440 \mathrm{H}$ (for 5000, 10000 or $20000 \mathrm{~g} \mathrm{~mol}^{-1}$ macromers, respectively) and compared to the integral of the protons corresponding to the incorporated molecule. ${ }^{2}$ Functionalization degrees of $>90 \%$ and yields of $>85 \%$ were obtained in all cases. Data was analyzed with MestReNova. UV/Vis spectra were recorded with a Varian Cary 4000 UV/Vis spectrometer (Varian Inc. Palo Alto, U.S.A.). FT-IR spectroscopy was recorded on 
a Bruker Vertex 70 spectrometer in the absorbance mode with film-casted samples using a diamond attenuated total reflectance (ATR) accessory.

Electrospray ionization mass spectrometry (ESI-MS) was recorded with a 1260 Infinity Liquid Chromatography/Mass Selective Detector (LC/MSD) (Agilent Technologies, DE) and Quadrupole Time-of-Flight (Q-TOF) with a 6545 Accurate-Mass Quadrupole Time-of-Flight (LC/Q-TOFMS) (Agilent Technologies, DE) using electrospray ionization.

The molar mass of PEG precursors was characterized by gel permeation chromatography (GPC). The GPC system comprised a Waters 515 HPLC Pump (Waters, Milford, U.S.A.), three GRAM PSS (Mainz, DE) columns in series (GRAM 30, GRAM 100, GRAM 100), a Waters 2410 refractive index detector and a Waters $2487 \mathrm{UV}$ detector (operating $\lambda=260 \mathrm{~nm}$ ). PEG standard kit of molar mass 7, 12, 26 and $44 \mathrm{kDa}$ (Jenkem, USA) was used for calibration and $1 \mathrm{~g} \mathrm{~L}^{-1} \mathrm{LiBr}$ in DMF was used as eluent. Runs were performed at $\mathrm{T}=60{ }^{\circ} \mathrm{C}$, flow $=1 \mathrm{~mL} \mathrm{~min}{ }^{-1}$, polymer concentration $=2.1 \mathrm{mg} \mathrm{mL}^{-1}$ in DMF.

\section{Synthesis of compounds}

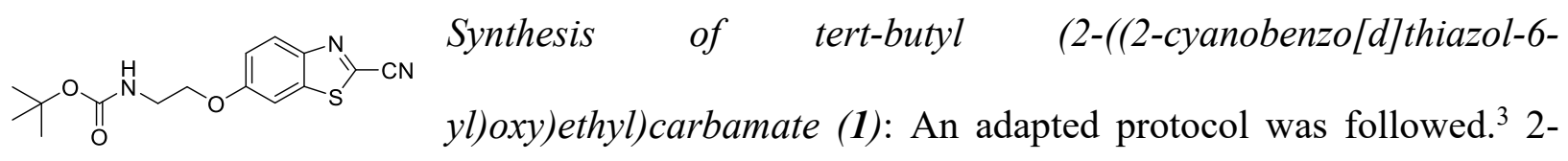
cyano-6-hydroxybenzothiazole (0.78 g, $4.45 \mathrm{mmol}, 1$ equiv.) was dissolved in dry DMF (20 mL), followed by addition of 2-(Boc-amino)ethyl bromide (2 g, 8.9 mmol, 2 equiv.) and $\mathrm{K}_{2} \mathrm{CO}_{3}(1.23$ $\mathrm{g}, 8.9 \mathrm{mmol}, 2$ equiv.) as solids. The mixture was stirred at $75^{\circ} \mathrm{C}$ overnight. The course of the reaction was monitored by analytic HPLC until complete consumption of the starting reagent. The reaction was quenched by addition of water $(20 \mathrm{~mL})$ and the aqueous layer was extracted with 
EtOAc four times. The combined organic layers were washed with saturated $\mathrm{NaHCO}_{3}$ solution twice, water and brine; dried over $\mathrm{MgSO}_{4}$, filtered and evaporated. Crude product was purified by flash chromatography (method: 30B-95B, A: MilliQ water, B: $\mathrm{ACN}$ ) to afford $0.77 \mathrm{~g}$ of pure compound as a white solid. (Yield $=55 \%$ ). Analytic HPLC (method: 30B-95B, $320 \mathrm{~nm}$ ): ret. time= 28 min. ESI-MS+: $320.0(\mathrm{M}+\mathrm{H}) .{ }^{1} \mathrm{H}-\mathrm{NMR}(300 \mathrm{MHz}$, acetone-d $6, \delta[\mathrm{ppm}])=8.12(1 \mathrm{H}, \mathrm{d},-\mathrm{CH}$ Ar); $7.81(1 \mathrm{H}, \mathrm{d},-\mathrm{CH} \mathrm{Ar}) ; 7.34$ (1H, dd, -CH Ar); 6.28 (1H, m, -NH amide); 4.22 (2H, t, -CH2); $3.57(2 \mathrm{H}, \mathrm{t},-\mathrm{CH} 2) ; 1.40(9 \mathrm{H}, \mathrm{s},-\mathrm{tBu}) .{ }^{13} \mathrm{C}-\mathrm{NMR}(75 \mathrm{MHz}$, acetone-d $6, \delta[\mathrm{ppm}])=160.65 ; 156.70$; $147.78 ; 138.58 ; 134.47 ; 126.36 ; 119.83 ; 114.10 ; 105.39 ; 78.92 ; 68.63 ; 40.45 ; 28.59$.

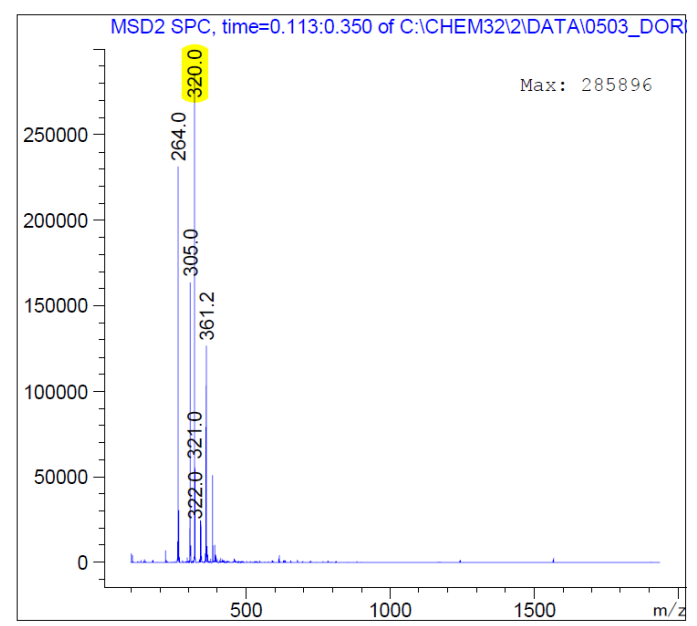



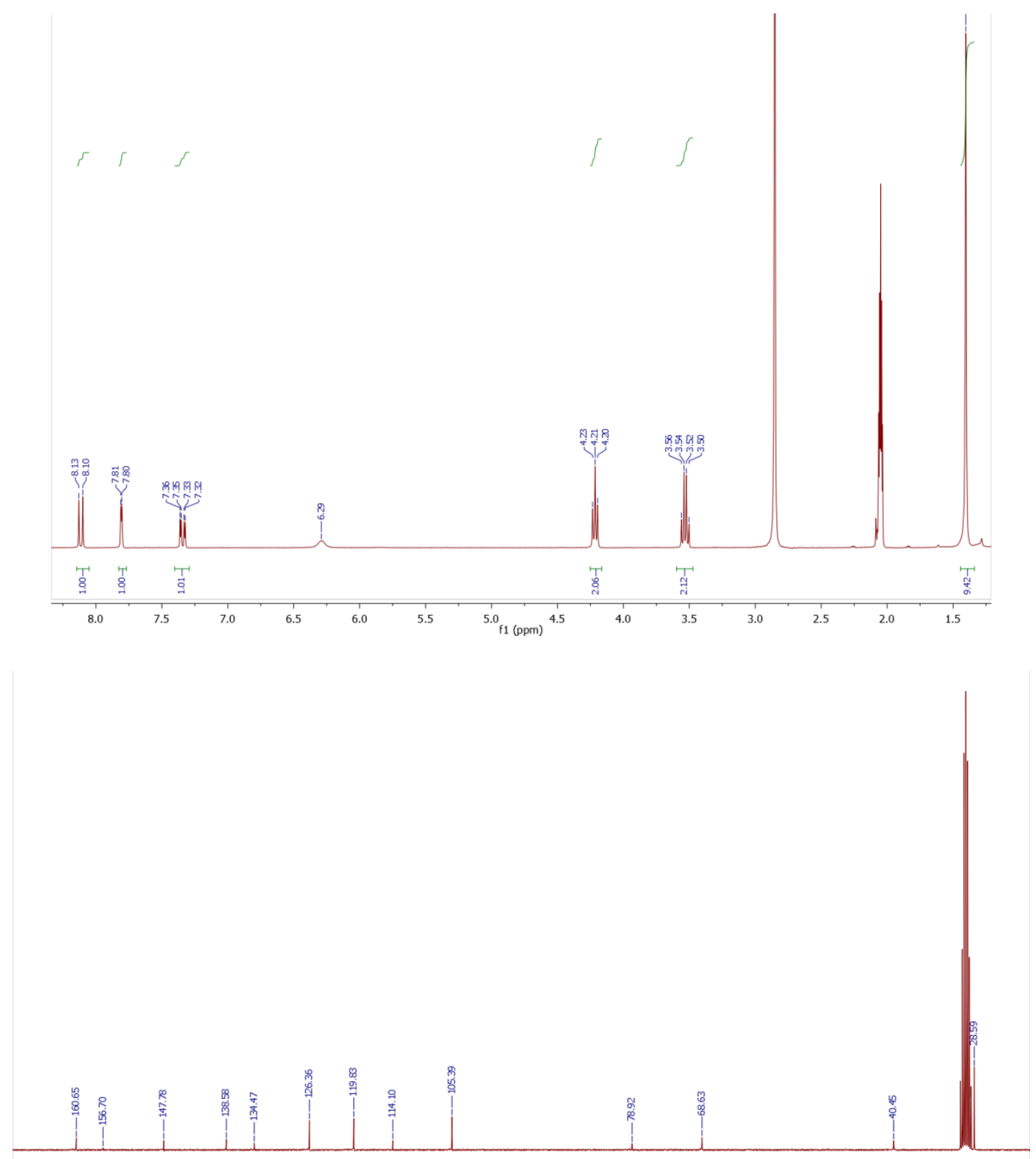

$\begin{array}{lllllllllllllllllllllllllllllllllllll}10 & 165 & 160 & 155 & 150 & 145 & 140 & 135 & 130 & 125 & 120 & 115 & 110 & 105 & 100 & 95 & 90 & 85 & 80 & 75 & 70 & 65 & 60 & 55 & 50 & 45 & 40 & 35 & 30 & 25\end{array}$

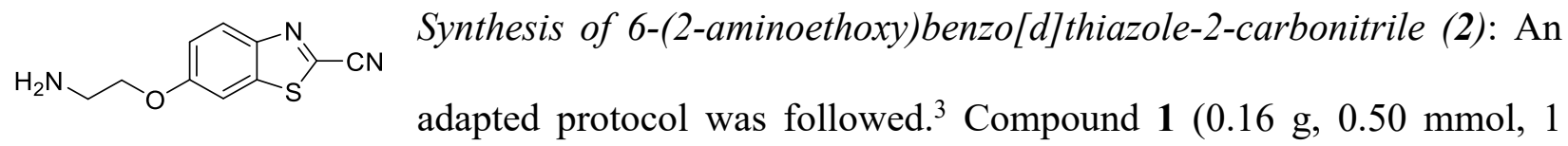
equiv.) was dissolved in dry DCM $(8 \mathrm{~mL})$ and cooled to $0^{\circ} \mathrm{C}$. Thioanisole $(1.1 \mathrm{~mL}, 10.0 \mathrm{mmol}, 20$ 
equiv.) was added and the mixture was stirred at $0^{\circ} \mathrm{C}$ for $3 \mathrm{~min}$. TFA $(1.1 \mathrm{~mL})$ was added slowly to the reaction vessel. The mixture was allowed to warm up to room temperature and stirring was continued. The course of the reaction was monitored by TLC (40\% EtOAc in hexane) until complete consumption of the starting reagent ( $\mathrm{ca} 1 \mathrm{~h}$ ). The crude was evaporated to reduce volume and dropped into cold diethylether. The obtained precipitate was isolated by centrifugation, purified by preparative HPLC (method: 5B-95B, $320 \mathrm{~nm}$ ) and freeze-dried to afford $74 \mathrm{mg}$ of compound 2 as a white solid (Yield= $67 \%$ ). Analytic HPLC (method: 5B-95B, $320 \mathrm{~nm}$ ): ret. time= 18 min. Q-ToF+: $220.1(\mathrm{M}+\mathrm{H}) .{ }^{1} \mathrm{H}-\mathrm{NMR}\left(300 \mathrm{MHz}\right.$, acetone- $\left.\mathrm{d}_{6}, \delta[\mathrm{ppm}]\right)=8.13(1 \mathrm{H}, \mathrm{d},-\mathrm{CH} \mathrm{Ar})$; $7.87(1 \mathrm{H}, \mathrm{d},-\mathrm{CH} \mathrm{Ar}) ; 7.36(1 \mathrm{H}, \mathrm{dd},-\mathrm{CH} \mathrm{Ar}) ; 4.61(2 \mathrm{H}, \mathrm{t},-\mathrm{CH} 2) ; 4.36(2 \mathrm{H}, \mathrm{t},-\mathrm{CH} 2) .{ }^{13} \mathrm{C}-\mathrm{NMR}$ $\left(75 \mathrm{MHz}\right.$, acetone- $\left.\mathrm{d}_{6}, \delta[\mathrm{ppm}]\right)=159.92 ; 148.23 ; 138.60 ; 135.15 ; 126.56 . ; 119.86 ; 114.13 ; 105.94$ $66.57 ; 47.62$.

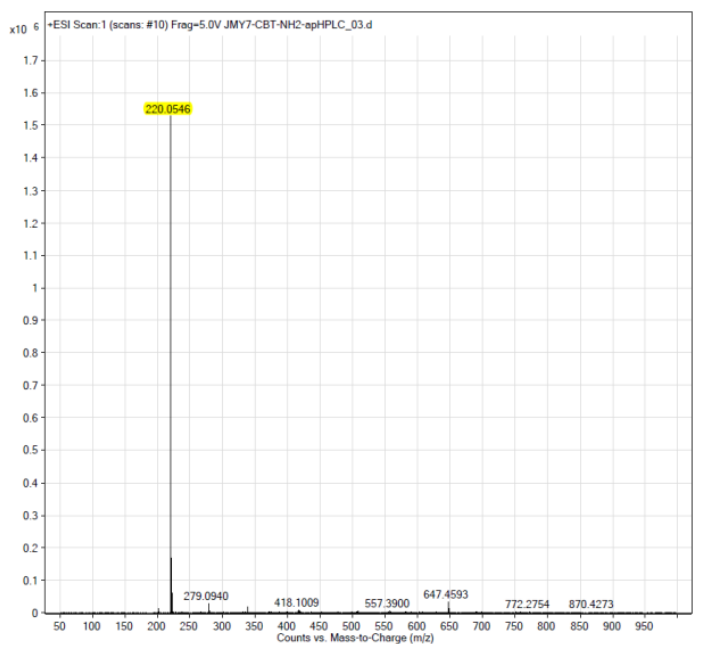




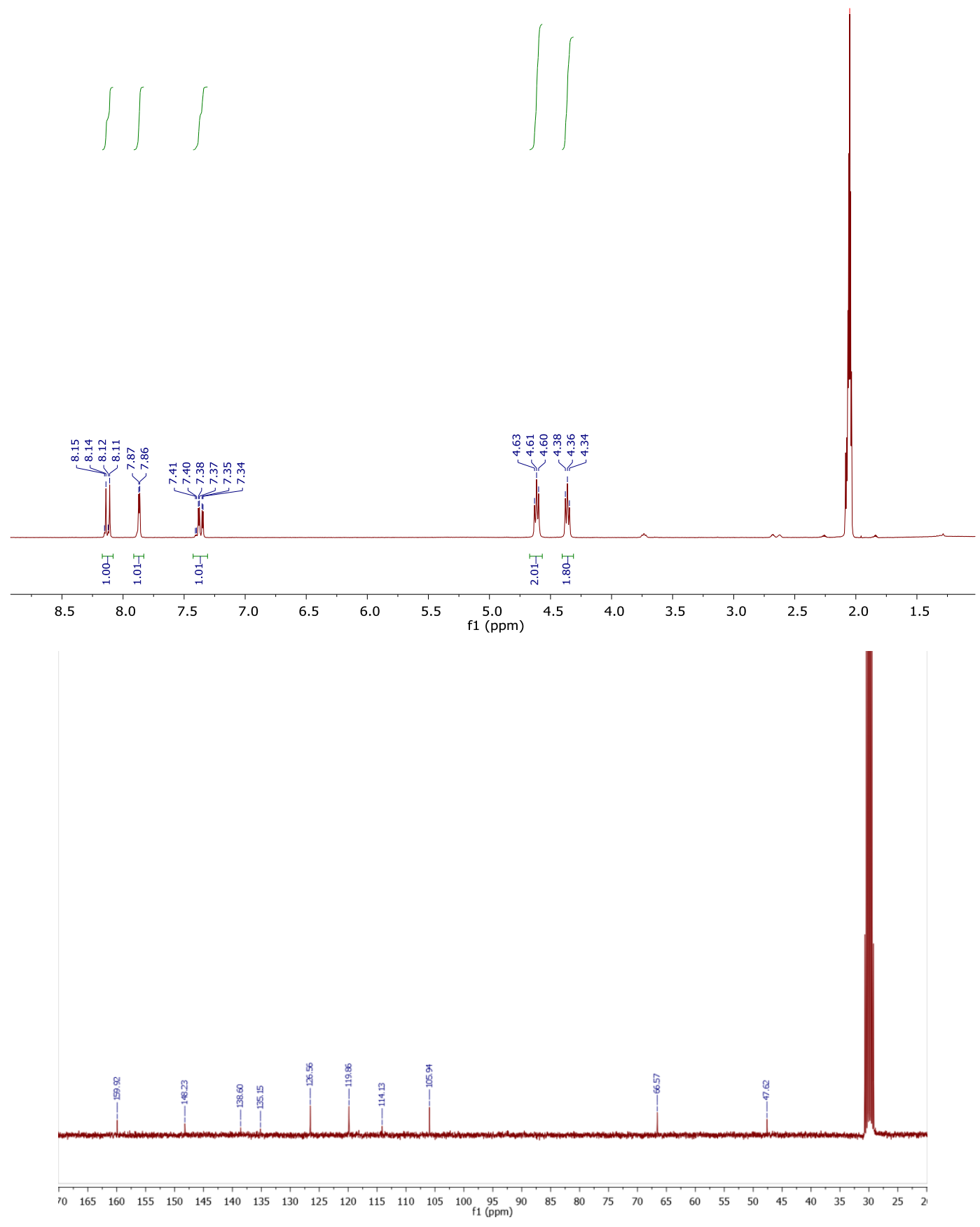

General protocols for the synthesis of PEG macromers. In the following, a typical procedure for polymer modification is described for a 4-arm, $10000 \mathrm{~g} \mathrm{~mol}^{-1}$ PEG macromer, unless otherwise stated. Similar procedure was followed for preparation of macromers of different multivalency (i.e., 8 -arm) and different molar mass (i.e., 5000 or $20000 \mathrm{~g} \mathrm{~mol}^{-1}$ ). 


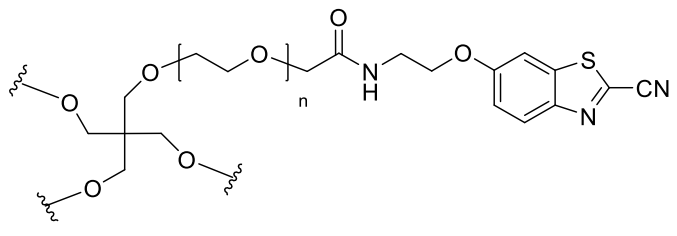

Synthesis of PEG-CBT: Compound $2(337 \mu \mathrm{mol}, 74$

$\mathrm{mg}$ ) and $\mathrm{N}$-methylmorpholine $(735 \mu \mathrm{mol}, 81 \mu \mathrm{L})$ were dissolved in dry DMF $(4 \mathrm{~mL})$, purged with nitrogen

and stirred for $15 \mathrm{~min}$. 4-arm PEG-NHS ( $350 \mathrm{mg}, 35 \mu \mathrm{mol})$ was dissolved in dry DMF (4 mL) and added to above solution under nitrogen stream. The mixture was stirred for three days at room temperature under inert atmosphere, then dialyzed in acetone and water, and freeze-dried. A white solid polymer was obtained and characterized by ${ }^{1} \mathrm{H}$ NMR in DCM- $\mathrm{d}_{2}$. Functionalization degree was calculated as $90 \%$. Yield $=85 \%$. The polymer prepared this way proved stable upon $>6$ months storage in the fridge (evidenced by no changes in ${ }^{1} \mathrm{H}-\mathrm{NMR}$ spectrum). ${ }^{1} \mathrm{H}-\mathrm{NMR}\left(500 \mathrm{MHz}, \mathrm{DCM}-\mathrm{d}_{2}, \delta[\mathrm{ppm}]\right)=8.10$ (d, -CH Ar); 7.46 (d, -CH Ar); 7.40 (m, -NH); 7.27 (dd, -CH Ar); 4.18 (t, -CH2); 3.97 (s, -CH2C=O PEG); 3.83 (t, -CH2); 3.80-3.35 (m, PEG core). 

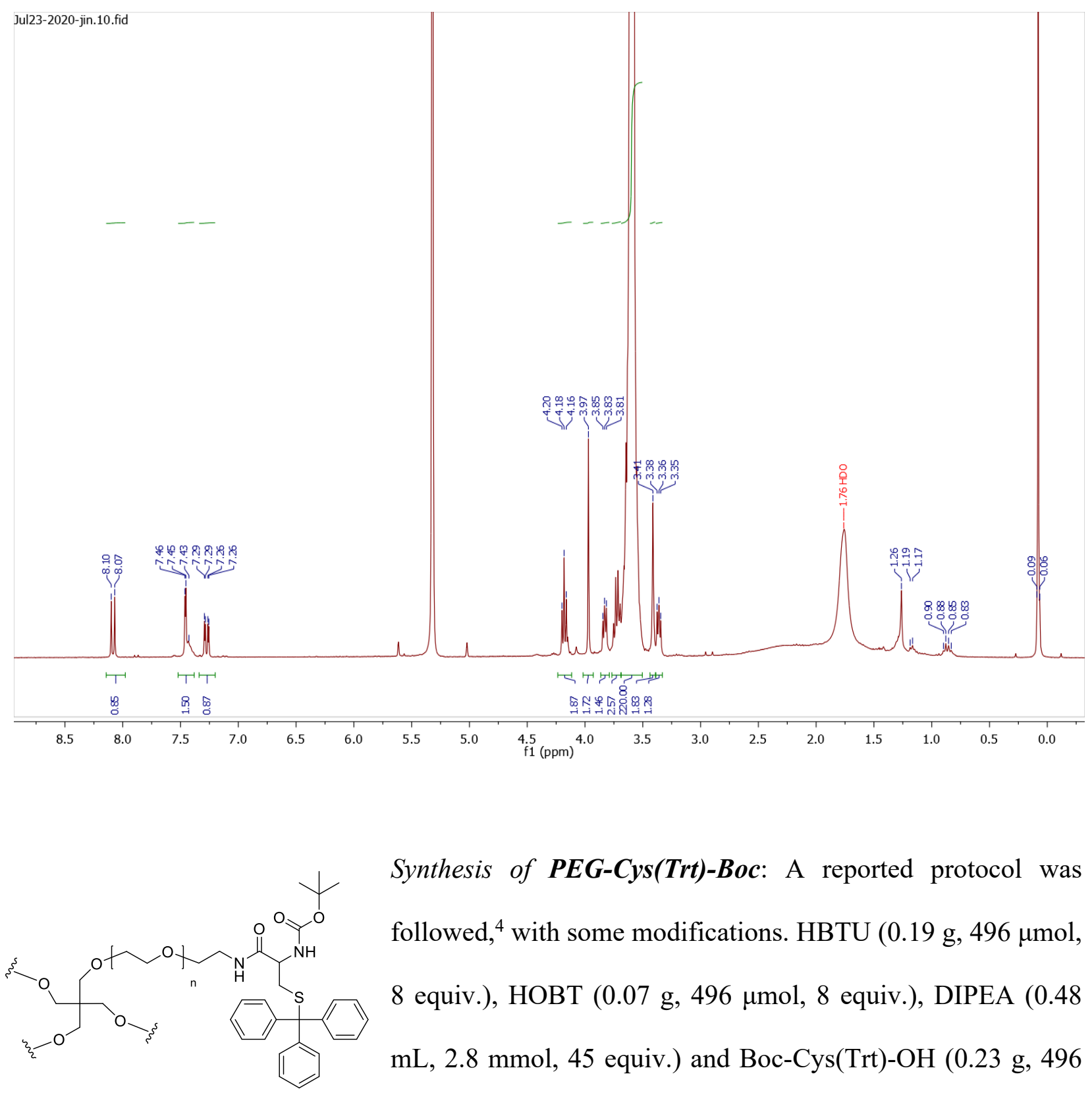

Synthesis of PEG-Cys(Trt)-Boc: A reported protocol was followed, ${ }^{4}$ with some modifications. HBTU $(0.19 \mathrm{~g}, 496 \mu \mathrm{mol}$, 8 equiv.), HOBT (0.07 g, $496 \mu$ mol, 8 equiv.), DIPEA ( 0.48 $\mathrm{mL}, 2.8 \mathrm{mmol}, 45$ equiv.) and Boc-Cys(Trt)-OH (0.23 g, 496 $\mu$ mol, 8 equiv.) were dissolved in dry DMF $(5 \mathrm{~mL})$ and added to a solution of PEG-amine $(0.62$ g, $62.5 \mu \mathrm{mol}, 1$ equiv.) in dry DMF (6 mL). The mixture was stirred at room temperature for 2 days. The crude was evaporated to reduce volume and dropped into cold diethylether. The obtained precipitate was isolated by centrifugation, dried under vacuum and characterized by ${ }^{1} \mathrm{H}$ NMR in DCM- $\mathrm{d}_{2} .0 .6 \mathrm{~g}$ of product were obtained (yield $=96 \%$ ). Functionalization degree was determined 
as $98 \% .{ }^{1} \mathrm{H}-\mathrm{NMR}(500 \mathrm{MHz}, \mathrm{DCM}-\mathrm{d} 2, \delta[\mathrm{ppm}])=7.95(\mathrm{~s},-\mathrm{NH}) ; 7.43-7.23(\mathrm{~m},-\mathrm{CH}$ Ar, Trt); 6.52 (s, -NH); 4.94 (s, -CH chiral); 3.84-3.31 (m, PEG chain); 2.58-2.46 (m, -CH2); 1.40 (s, -tBu, Boc).
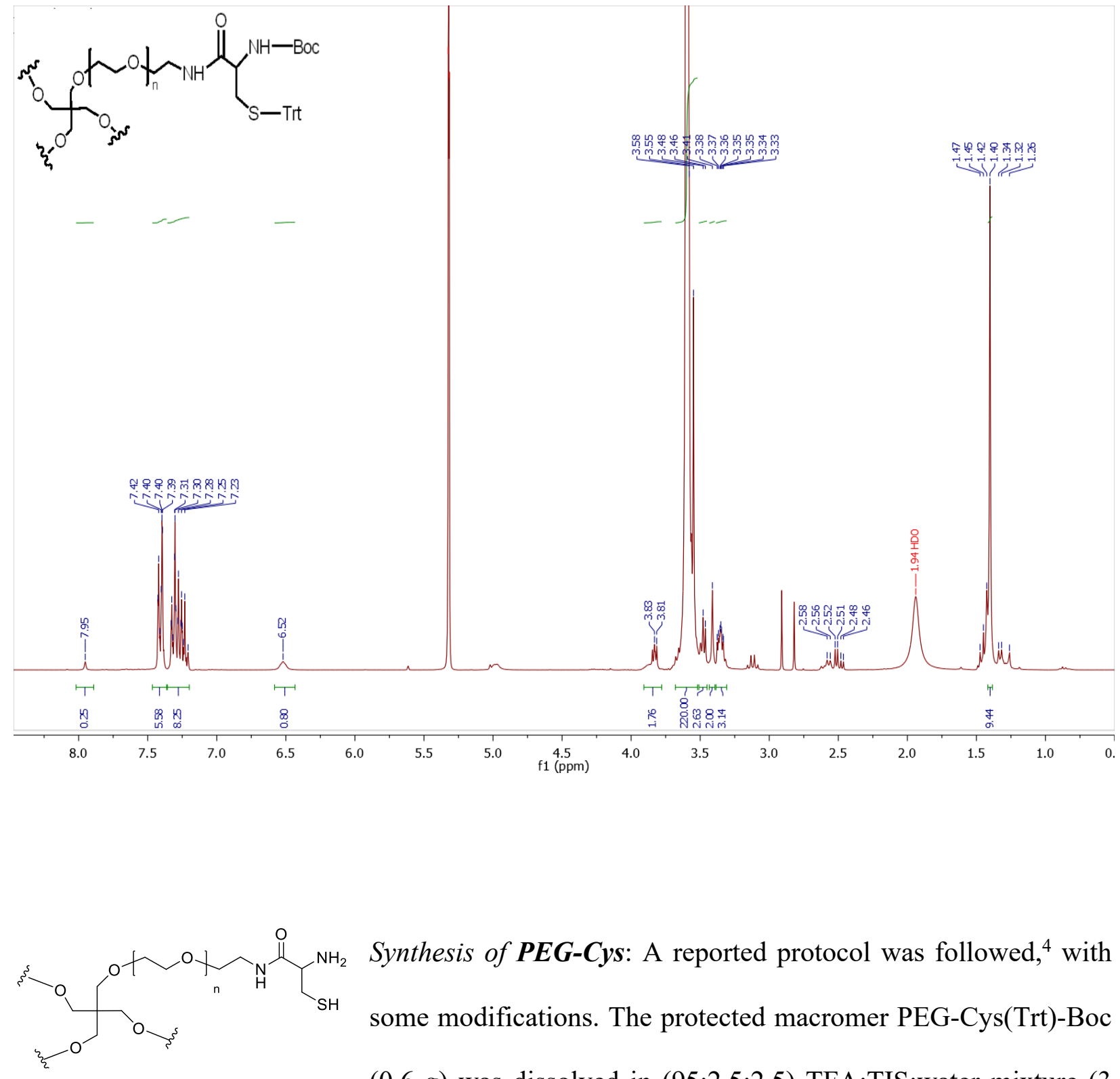

Synthesis of PEG-Cys: A reported protocol was followed, ${ }^{4}$ with some modifications. The protected macromer PEG-Cys(Trt)-Boc (0.6 g) was dissolved in (95:2.5:2.5) TFA:TIS:water mixture (3 $\mathrm{mL}$ ) and reacted for $1.5 \mathrm{~h}$ at room temperature. The crude was evaporated under nitrogen stream to reduce volume and dropped into cold diethylether. The obtained precipitate was isolated by centrifugation, then dialyzed in acetone and water, and freeze-dried. A white solid polymer was obtained $(0.51 \mathrm{~g}$, yield $=85 \%)$ and characterized by ${ }^{1} \mathrm{H}$ NMR in DCM- $\mathrm{d}_{2}$, which proved complete 
removal of protecting groups and functionalization degree was calculated as $>99 \%$. ${ }^{1} \mathrm{H}-\mathrm{NMR}(500$ MHz, DCM-d2, $\delta[\mathrm{ppm}])=8.13(\mathrm{~s},-\mathrm{NH}) ; 4.33-4.29$ (t, -CH chiral); 3.74-3.45 (m, PEG chain); $3.42-3.39$ $(\mathrm{m}$, $-\mathrm{CH})$ and $3.15-3.05$

$(\mathrm{m}$, $-\mathrm{CH})$.<smiles>CCOC(OC)(OC)C(C)OCCNC(=O)C(N)CS</smiles><smiles>CCOCCOCCOCC(=O)NCCOc1ccc2nc(-c3nc(C(C)=O)cs3)sc2c1</smiles>

Synthesis of model macromer PEG-LuciferinOMe: 4A, $5000 \mathrm{~g} \mathrm{~mol}^{-1}$ PEG-CBT macromer (27 mg, $5.4 \mathrm{mmol}, 1$ equiv.) was dissolved in MilliQ water ( $3 \mathrm{~mL})$. An aqueous solution of H-Cys-OMe ( $8 \mathrm{mg}, 45 \mathrm{mmol}, 8.4$ equiv.) (1.5 mL, containing $12.4 \mathrm{mg}$ TCEP and $45 \mathrm{mg} \mathrm{NaHCO}_{3}$ ) was prepared and added to above PEG-CBT precursor solution and reacted at room temperature for $2 \mathrm{~h}$. The obtained yellow-green crude was dialyzed in water and freeze-dried. A green solid polymer was obtained and characterized by ${ }^{1} \mathrm{H}$ 
NMR in DCM-d $2 .{ }^{1} \mathrm{H}-\mathrm{NMR}(500 \mathrm{MHz}, \mathrm{DCM}-\mathrm{d} 2, \delta[\mathrm{ppm}])=8.10-7.90(\mathrm{~m},-\mathrm{CH}$ Ar), 7.50-7.35 (m, - $\mathrm{CH}$ Ar and -NH), 7.27-7.07 (m, -CH Ar), 6.05-5.85 (br m, -CH chiral), 4.22-4.10 (m, $\mathrm{NHCH} 2 \mathrm{CH} 2 \mathrm{O}), 3.97(\mathrm{~m},-\mathrm{CH} 2 \mathrm{C}=\mathrm{O}), 3.75-3.40(\mathrm{~m},-\mathrm{NHCH} 2 \mathrm{CH} 2 \mathrm{O}, \mathrm{PEG}$ core, -OMe and $\mathrm{CH} 2 \mathrm{CH})$.

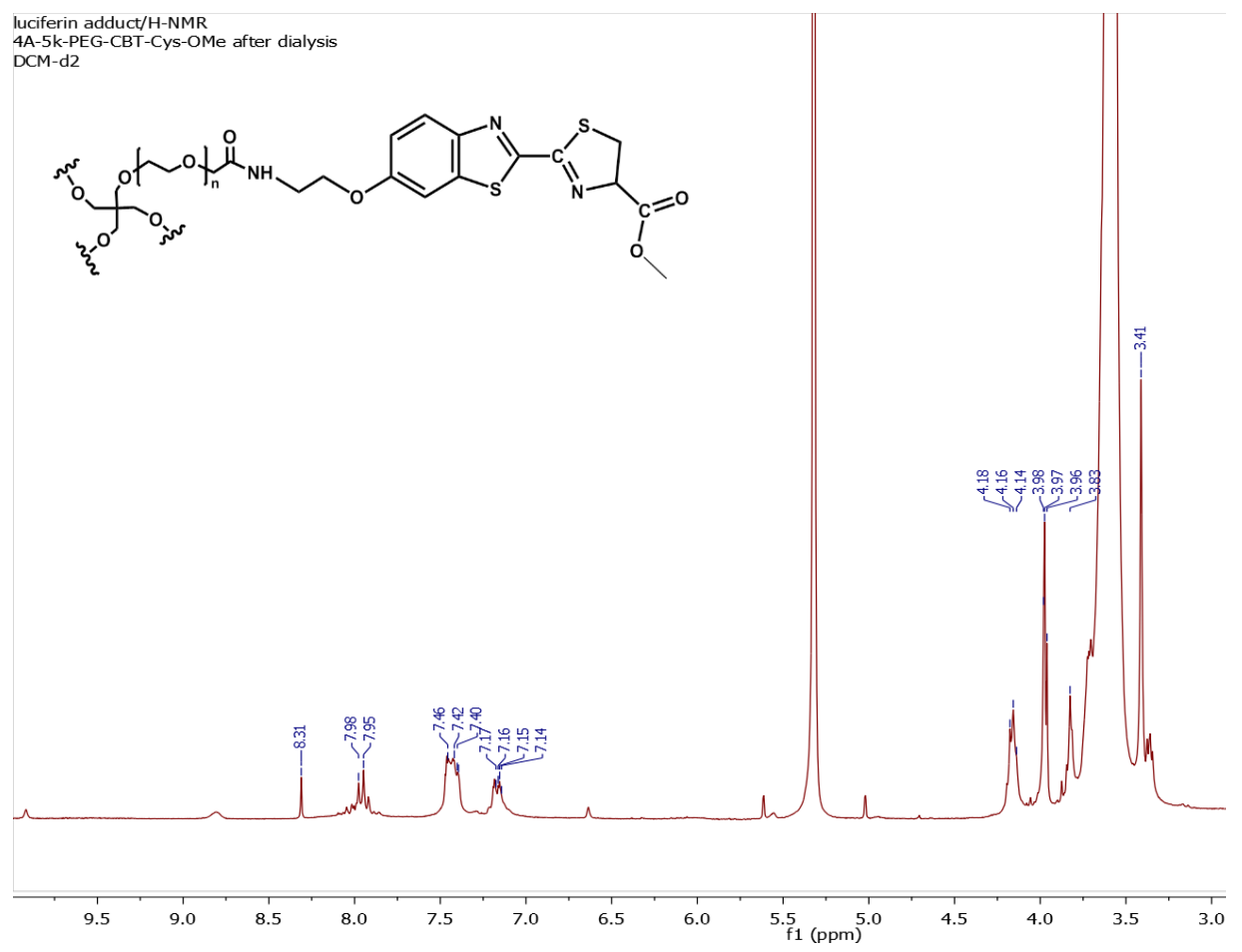




\section{GPC characterization of PEG-CBT precursors}

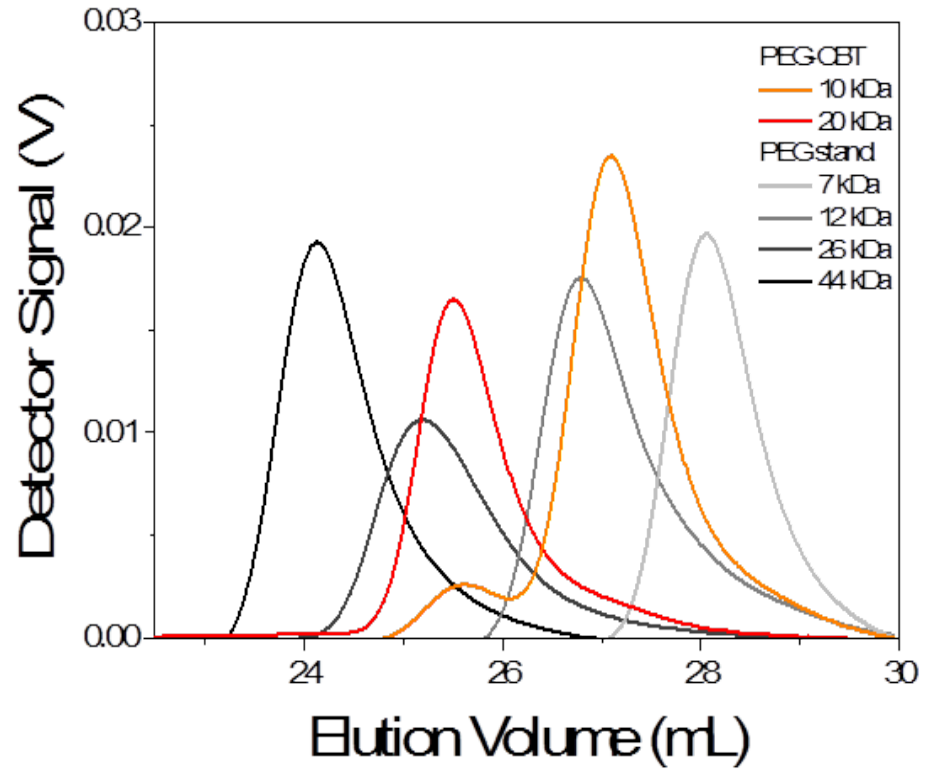

Table S3. GPC results of the different PEG-CBT precursors.

\begin{tabular}{|c|c|c|}
\hline PEG-CBT precursor & $\begin{array}{c}\mathbf{1 0} \mathbf{~ k D a} \\
\left.\mathbf{( 1 0 0 0 0} \mathbf{~} ~ \mathbf{~ m o l}^{-\mathbf{1}}\right)\end{array}$ & $\begin{array}{c}\mathbf{2 0} \mathbf{~ k D a} \\
\left.\mathbf{( 1 0 0 0 0} \mathbf{~} \mathbf{~ m o l}^{-\mathbf{1}}\right)\end{array}$ \\
\hline $\begin{array}{c}\mathbf{M}_{\mathbf{n}} \\
{\left[\mathrm{g} \mathrm{mol}^{-1}\right]}\end{array}$ & 8389 & 18503 \\
\hline $\begin{array}{c}\mathbf{M}_{\mathbf{w}} \\
{\left[\mathrm{g} \mathrm{mol}^{-1}\right]}\end{array}$ & 11030 & 20670 \\
\hline $\begin{array}{c}\mathbf{M}_{\mathbf{z}} \\
{\left[\mathrm{g} \mathrm{mol}^{-1}\right]}\end{array}$ & 14168 & 22330 \\
\hline $\begin{array}{c}\mathbf{M}_{\mathbf{p}} \\
{\left[\mathrm{g} \mathrm{mol}^{-1}\right]}\end{array}$ & 10564 & 22846 \\
\hline $\mathbf{D}$ & 1.3148 & 1.1171 \\
\hline
\end{tabular}

\section{Supplementary cell studies}

\section{Cell culture}

Fibroblast L929 cell line (ATCC) was cultured at $37^{\circ} \mathrm{C}$ and $5 \% \mathrm{CO}_{2}$ in complete medium (RPMI 1640 (Gibco, 61870-010) supplemented with 10\% FBS (Gibco, 10270), $100 \mathrm{U} \mathrm{mL}^{-1}$ penicillin and $100 \mu \mathrm{g} \mathrm{mL} \mathrm{m}^{-1}$ streptomycin (Invitrogen)) as established in the literature. ${ }^{5}$ For the encapsulation 
experiments, L929 cells were counted and resuspended in serum free medium to achieve a final cell density of 20000 cells per gel, unless otherwise stated. ${ }^{6-7}$

\section{Hydrogel Preparation for $3 D$ cell culture of fibroblasts}

CBT-Cys hydrogels were prepared by adapting previously reported protocols. ${ }^{2,}$ 7-8 Precursor solutions of 4-arm, $20000 \mathrm{~g} \mathrm{~mol}^{-1}$ PEG-CBT $\left(100 \mathrm{mg} \mathrm{mL}^{-1}, 10 \mathrm{wt} \%\right)$ were prepared by dissolving the lyophilized polymer in sterile $20 \mathrm{mM}$ HEPES buffer $\mathrm{pH} 8.0$ inside a sterile laminar flow and used directly without further filtration. Solutions of cyclo(RGDfK(C)) $\left(3.5 \mathrm{mg} \mathrm{mL}^{-1}, 5 \mathrm{mM}\right)$, and VPM peptide (31.9 $\mathrm{mg} \mathrm{mL}^{-1}, 17.5 \mathrm{mM}$ ) were prepared in sterile HEPES buffer $\mathrm{pH} 8.0$ containing 1 equiv. of TCEP per Cys equiv. and $178 \mathrm{mM} \mathrm{NaHCO}_{3}$. PEG-CBT stock solution $(4 \mu \mathrm{L}, 10 \mathrm{wt} \%)$ was mixed with cyclo(RGDfK(C)) $(2 \mu \mathrm{L}, 5 \mathrm{mM})$ and incubated for $30 \mathrm{~min}$ at $37^{\circ} \mathrm{C}$. The fibroblast cell suspension $\left(1 \times 10^{7}\right.$ cells $\mathrm{mL}^{-1}$, cell density within the typical range of $3 \times 10^{5}-3 \times 10^{7}$ cells $\mathrm{mL}^{-}$ ${ }^{1}$ as reported in published work $\left.{ }^{6-12}\right)$ in serum free RPMI medium $(2 \mu \mathrm{L})$ was added to the above solution and $8 \mu \mathrm{L}$ of resulting mixture were placed in an Ibidi $15-\mu$ well angiogenesis slide. Immediately, the solution of VPM peptide $(2 \mu \mathrm{L}, 17.5 \mathrm{mM})$ was added to the $\mu$-well, carefully mixed with pipette tip and allowed to crosslink (hence 8:2 mixing). Final gel composition (+VPM / +RGD condition) was $4 \mathrm{wt} \%$ PEG-CBT, $0.06 \mathrm{wt} \%(1 \mathrm{mM})$ cyclo(RGDfK(C)), $0.64 \mathrm{wt} \%$ (3.5 mM) VPM. Final cell density in hydrogels was 20000 cells per gel. CBT-Cys hydrogels were cured for 15 min at $37{ }^{\circ} \mathrm{C}$ and $5 \% \mathrm{CO}_{2}$. After gelation, complete RPMI medium $(45 \mu \mathrm{L})$ was added to rinse the gel for $10 \mathrm{~min}$, medium was replenished again, and culture was maintained up to 6 days. Medium was exchanged every other day. Thiol-VS gels of identical composition were prepared similarly, except that they were cured for $45 \mathrm{~min}$, and used as control. 


\section{DAPI staining and study of cell density distribution across the gel}

Experiments were performed in triplicates. In order to study the homogeneity of cell encapsulation in CBT-Cys hydrogels, L929 fibroblasts were encapsulated following a 1:1 volume mixing protocol as applied for hMSC culture (see main text). Cells were then cultured in CBTCys hydrogels (at 2500 cells per gel, to have a lower cell density for visualization) for 1 day and cell culture medium was removed. Samples were mildly permeabilized with $0.1 \%$ Triton-X-100 (in PBS) for $1 \mathrm{~h}$ at room temperature and then incubated in 1:1000 DAPI solution in PBS for nuclear labeling (at $4^{\circ} \mathrm{C}$, overnight). Samples were washed $4 \mathrm{X}$ for 10 min in PBS and imaged with Zeiss LSM 880 confocal microscope with a 10X air objective, using Z-stack mode and $10 \mu \mathrm{m}$ per stack. The cell distribution across the gel was qualitatively analyzed by constructing 3D representation of z-stack images using Imaris image analysis software (Oxford Instruments, UK).

\section{Live/dead Assay}

All experiments were performed in triplicates. L929 fibroblasts were cultured in CBT-Cys hydrogels for 1, 3 and 6 days and cell culture medium was removed. Samples were incubated for 5 min with fluorescein diacetate $\left(40 \mu \mathrm{g} \mathrm{mL}^{-1}\right)$ and propidium iodide $(30 \mu \mathrm{g} \mathrm{mL}-1)$ in PBS, washed twice with PBS and imaged with Zeiss Axio Observer microscope with corresponding filter settings and using a 10X air objective. Cells were kept in PBS and imaging was done at normal cell culture conditions (at $37{ }^{\circ} \mathrm{C}$ and $5 \% \mathrm{CO}_{2}$ in a humidified environment) in a climate chamber connected to the microscope within $1 \mathrm{~h}$ of staining. Excitation parameters were adjusted to use minimum light intensity in order to maintain cytocompatibility. For each sample, imaging was performed across different z-stacks in three different wells per condition, and at least 600 
individual cells were counted manually using Image $J$ to calculate the percentage viability of each sample.

Statistical analysis. Cell viability data were expressed as mean \pm standard deviation (SD). For each condition, 3 independent experiments were performed. A one-way analysis of variance (ANOVA) with a Tukey test of the variance was used to determine the statistical significance between groups. The statistical analysis was performed to compare different groups and significant difference was set to $* \mathrm{p}<0.05$.

References

(1) Qing, Y.; Liu, M. D.; Hartmann, D.; Zhou, L.; Ramsay, W. J.; Bayley, H. Single-Molecule Observation of Intermediates in Bioorthogonal 2-Cyanobenzothiazole Chemistry. Angew. Chem. Int. Ed. 2020, 59 (36), 15711-15716, DOI: https://doi.org/10.1002/anie.202005729.

(2) Paez, J. I.; Farrukh, A.; Valbuena-Mendoza, R.; Włodarczyk-Biegun, M. K.; del Campo, A. Thiol-Methylsulfone-Based Hydrogels for 3D Cell Encapsulation. ACS Appl. Mater. Interfaces 2020, 12 (7), 8062-8072, DOI: 10.1021/acsami.0c00709.

(3) Chen, K.-T.; Ieritano, C.; Seimbille, Y. Early-Stage Incorporation Strategy for Regioselective Labeling of Peptides using the 2-Cyanobenzothiazole/1,2-Aminothiol Bioorthogonal Click Reaction. ChemistryOpen 2018, 7 (3), 256-261, DOI: doi:10.1002/open.201700191.

(4) Hu, B. H.; Su, J.; Messersmith, P. B. Hydrogels Cross-Linked by Native Chemical Ligation. Biomacromolecules 2009, 10 (8), 2194-2200, DOI: 10.1021/bm900366e.

(5) Takeuchi, A.; Hayashi, H.; Naito, Y.; Baba, T.; Tamatani, T.; Onozaki, K. Human Myelomonocytic Cell Line THP-1 Produces a Novel Growth-promoting Factor with a Wide Target Cell Spectrum. Cancer Res. 1993, 53 (8), 1871-1876.

(6) Lee, S.-H.; Moon, J. J.; West, J. L. Three-Dimensional Micropatterning of Bioactive Hydrogels via Two-Photon Laser Scanning Photolithography for Guided 3D Cell Migration. Biomaterials 2008, 29 (20), 2962-2968, DOI: https://doi.org/10.1016/j.biomaterials.2008.04.004.

(7) Phelps, E. A.; Enemchukwu, N. O.; Fiore, V. F.; Sy, J. C.; Murthy, N.; Sulchek, T. A.; Barker, T. H.; García, A. J. Maleimide Cross-Linked Bioactive PEG Hydrogel Exhibits Improved Reaction Kinetics and Cross-Linking for Cell Encapsulation and In Situ Delivery. Adv. Mater. 2012, 24 (1), 64-70, DOI: 10.1002/adma.201103574.

(8) Farrukh, A.; Paez, J. I.; del Campo, A. 4D Biomaterials for Light-Guided Angiogenesis. Adv. Funct. Mater. 2019, 29 (6), 1807734, DOI: doi:10.1002/adfm.201807734.

(9) Bott, K.; Upton, Z.; Schrobback, K.; Ehrbar, M.; Hubbell, J. A.; Lutolf, M. P.; Rizzi, S. C. The Effect of Matrix Characteristics on Fibroblast Proliferation in 3D Gels. Biomaterials 2010,31 (32), 8454-8464, DOI: https://doi.org/10.1016/j.biomaterials.2010.07.046. 
(10) Moon, J. J.; Saik, J. E.; Poché, R. A.; Leslie-Barbick, J. E.; Lee, S.-H.; Smith, A. A.; Dickinson, M. E.; West, J. L. Biomimetic hydrogels with pro-angiogenic properties. Biomaterials 2010, 31 (14), 3840-3847, DOI: https://doi.org/10.1016/j.biomaterials.2010.01.104.

(11) Adelöw, C.; Segura, T.; Hubbell, J. A.; Frey, P. The Effect of Enzymatically Degradable Poly(Ethylene Glycol) Hydrogels on Smooth Muscle Cell Phenotype. Biomaterials 2008, 29 (3), 314-326, DOI: https://doi.org/10.1016/j.biomaterials.2007.09.036.

(12) DeForest, C. A.; Anseth, K. S. Cytocompatible Click-Based Hydrogels with Dynamically Tunable Properties Through Orthogonal Photoconjugation and Photocleavage Reactions. Nat. Chem. 2011, 3, 925-931, DOI: 10.1038/nchem.1174. 